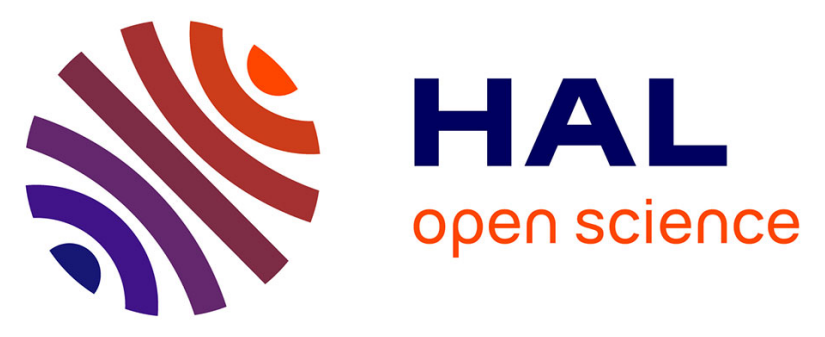

\title{
Regeneration of Hopcalite used for the adsorption plasma catalytic removal of toluene by non-thermal plasma
}

Savita Kaliya Perumal Veerapandian, Jean-Marc Giraudon, Nathalie de Geyter, Yuliia Onyshchenko, Chidharth Krishnaraj, Shilpa Sonar, Axel Löfberg, Karen Leus, Pascal van Der Voort, Jean-Francois Lamonier, et al.

\section{To cite this version:}

Savita Kaliya Perumal Veerapandian, Jean-Marc Giraudon, Nathalie de Geyter, Yuliia Onyshchenko, Chidharth Krishnaraj, et al.. Regeneration of Hopcalite used for the adsorption plasma catalytic removal of toluene by non-thermal plasma. Journal of Hazardous Materials, 2021, 402, pp.123877. 10.1016/j.jhazmat.2020.123877 . hal-02974179

\section{HAL Id: hal-02974179 \\ https://hal.univ-lille.fr/hal-02974179}

Submitted on 21 Oct 2020

HAL is a multi-disciplinary open access archive for the deposit and dissemination of scientific research documents, whether they are published or not. The documents may come from teaching and research institutions in France or abroad, or from public or private research centers.
L'archive ouverte pluridisciplinaire HAL, est destinée au dépôt et à la diffusion de documents scientifiques de niveau recherche, publiés ou non, émanant des établissements d'enseignement et de recherche français ou étrangers, des laboratoires publics ou privés. 


\section{Regeneration of Hopcalite used for the adsorption plasma catalytic removal of toluene by non-thermal plasma}

$\underline{\text { Savita Kaliya Perumal Veerapandian }}{ }^{1}$, Jean-Marc Giraudon ${ }^{2}$, Nathalie De Geyter ${ }^{1}$, Yuliia

Onyshchenko ${ }^{1}$, Chidharth Krishnaraj ${ }^{3}$, Shilpa Sonar ${ }^{1,2}$, Axel Löfberg ${ }^{2}$, Karen Leus ${ }^{3}$, Pascal Van Der Voort ${ }^{3}$, Jean-François Lamonier ${ }^{2}$, Rino Morent ${ }^{1}$

${ }^{I}$ Ghent University, Faculty of Engineering and Architecture, Department of Applied Physics,

Research Unit Plasma Technology, Sint-Pietersnieuwstraat 41 B4, 9000 Ghent, Belgium

${ }^{2}$ Univ. Lille, CNRS, Centrale Lille, Univ. Artois, UMR 8181 - UCCS - Unité de

Catalyse et Chimie du Solide, F-59000 Lille, France

${ }^{3}$ Ghent University, Department of Chemistry, COMOC-Center for Ordered Materials,

Organometallics and Catalysis, Krijgslaan 281-S3, 9000 Ghent, Belgium

Savita.kaliyaperumalveerapandian@ugent.be

tel.: +32-(0)9-264.38.38; fax: +32-(0)9-264.41.98 
Abstract. A dielectric barrier discharge reactor packed with both Hopcalite \& glass beads has been investigated for the total oxidation of toluene adsorbed on Hopcalite. The catalytic activity and selectivity through the possible formation of by-products during the NTP discharge for the abatement of irreversibly adsorbed toluene have been investigated by FT-IR and mass spectrometer. The regeneration of the used Hopcalite by NTP discharge has been established by (i) determining the amount of toluene adsorbed on NTP regenerated Hopcalite, (ii) investigating the catalytic activity of NTP regenerated Hopcalite and (iii) comparing the bulk and surface properties of the fresh calcined and NTP regenerated Hopcalite. The ratio of amount of irreversibly adsorbed toluene to that of the total amount of adsorbed toluene adsorbed is similar for the fresh calcined and NTP (I) regenerated Hopcalite. The catalytic activity of the NTP (I) regenerated Hopcalite is slightly enhanced when compared to that of the fresh calcined Hopcalite. Although the first NTP treatment induces partial transformation of Hopcalite into $\mathrm{Mn}_{3} \mathrm{O}_{4}$ with no detected related $\mathrm{CuO}_{\mathrm{x}}$ and reduces specific surface area by a factor of 2 , the toluene adsorption capacity remains less affected. A plausible reaction scheme for toluene decomposition in Hopcalite PBDBD reactor is proposed.

Keywords: Adsorption plasma catalysis; Toluene abatement; Regeneration by NTP; Hopcalite; Packed bed DBD 


\section{Introduction}

Volatile organic compounds (VOCs) are one of the major sources of indoor air pollution [1] and considered to be one of the main causes of sick building syndrome [2] with symptoms including eye irritation, sore throat and headaches. Among the various VOCs, toluene is believed to be widely present in indoor and outdoor air [3] due its application as solvents. Aromatic hydrocarbons including toluene play an important role in the formation of ground level ozone, aerosols and smog [4]. Due to its effects on human health and environment, their elimination from the atmosphere is of prime importance and numerous works have been carried out for the efficient removal of VOCs. Various technologies such as adsorption [5-7], thermal, catalytic $[8,9]$ and photocatalytic oxidation [10], non-thermal plasma (NTP) [11], biological methods (biofiltration, bioscrubbers, etc.,) $[12,13]$ etc., have been extensively investigated for the removal of VOCs from air.

In the last two decades, NTP has been proven to be a useful technique for simultaneous removal of different VOCs of low concentration at ambient conditions [14-16]. But the main drawbacks of VOCs removal by NTP such as low energy efficiency and formation of unwanted by-products such as ozone, nitrogen oxides and other toxic organic compounds [17] hinder the commercialization of this technique. As an alternative technique, researchers have shown that plasma catalysis (the combination of NTP and catalysts) enhances the VOC removal efficiency and reduces the formation of unwanted by-products [18]. The catalysts can be placed either in 
NTP discharge region (in plasma catalysis, IPC) or placed in the downstream of the NTP discharge (post plasma catalysis, PPC). Recently several catalysts such as individual and binary metal oxides [19,20], metal loaded on supports [21,22] and supported metal oxides [23,24] have been investigated for the plasma catalytic removal of toluene from air.

Even though, plasma catalysis has been proven to be more efficient than the individual techniques such as NTP and catalytic oxidation, the plasma discharge is continuously operating which results in higher energy consumption [25]. Recently, an alternative approach of adsorption plasma catalysis (APC), also known as cycled 'storage-discharge' (CSD) has been proposed and investigated to mitigate the energy cost of the process [26,27]. This technique involves two steps as follows: (i) first, VOC in low concentration is trapped/adsorbed on the adsorbent and (ii) then, the trapped/adsorbed VOC is oxidized by NTP discharge. For this approach of adsorption plasma catalysis, one of the key factors is to find a suitable dual functional material which has the following properties: (i) high capability of adsorption which reduces the energy cost (EC) of the APC process [28], a higher ratio of adsorption time $\left(t_{1}\right)$ to the NTP discharge time $\left(t_{2}\right)$ means lower energy cost $\left(E C_{A P C}=\frac{P_{\text {discharge }} t_{2}}{F_{1} t_{1}}\right)$, (ii) ability for the total oxidation of the adsorbed VOC to avoid the formation of unwanted toxic by-products, (iii) stability of the catalyst in the NTP discharge and (iv) ability to be regenerated by the NTP discharge, to avoid the extra step of calcination to regenerate the catalyst [29]. Dhal et al [30] proposed that the regeneration of Hopcalite can be carried out by washing, drying and/or 
calcination depending on the deactivation mechanism. For example, coke removal from Hopcalite is effective by heating the catalyst to $550{ }^{\circ} \mathrm{C}$. Xu et al reported that the approach of APC slightly improved the toluene conversion efficiency and significantly improved the carbon balance when compared to the convention plasma catalysis [21]. Fan et al reported the complete oxidation of benzene adsorbed on Ag/HZSM-5 by an APC approach with an energy cost as low as $3.7 \times 10^{-3} \mathrm{kWhm}^{-3}$ [31]. Sivachandran et al reported that the energy required to remove the same amount of isopropyl alcohol by an APC technique is 14.5 times lesser than that of the continuous discharge method [32]. Zhao et al investigated the different metal loaded HZSM-5 catalysts for the removal of formaldehyde by APC and reported that AgCu/HZSM-5 exhibited excellent humidity tolerance, low energy cost and almost no formation of secondary byproducts [28]. The above-mentioned works demonstrated the stability of the catalysts in NTP discharges by comparing the amount of VOCs adsorbed and the catalytic activity during NTP discharge for used and fresh catalysts. However, the surface and bulk properties of the catalysts can change after exposure to NTP discharge. Very recently, the effect of NTP plasma on the oxidation state and morphology of metal oxide catalysts has been reported. Ansari et al discussed the changes in $\mathrm{S}_{\mathrm{BET}}$, surface morphology and surface oxidation state of $\mathrm{ZnO} / \alpha-\mathrm{Fe}_{2} \mathrm{O}_{3}$ catalyst. They also observed that there is no change in crystallinity after exposure to air plasma [33]. Thus, it is important to gain more insight about the stability of catalysts in a NTP discharge. In this work, Hopcalite (Purelyst MD101), a commercial Cu-Mn oxide based mixed oxide 
catalyst is used for the adsorption plasma catalytic removal of toluene. Hopcalite is one of the traditional catalysts mainly used in devices for respiratory protection due to its good $\mathrm{CO}$ oxidation ability [34]. Different works have shown that $\mathrm{Cu}-\mathrm{Mn}$ based oxides including commercial Hopcalite can be efficient catalysts in the oxidation of toluene at moderate temperatures [35]. Li et al showed that the $\mathrm{Cu}-\mathrm{Mn}$ mixed oxide catalyst is efficient for the catalytic oxidation of toluene [36]. Hopcalite has been used at elevated temperature for the oxidation of different VOCs [36,37], but it has low catalytic activity at ambient temperature [38]. On the other hand, plasma catalysis has been proven to show synergic effects at lower catalyst temperature and specific input energy of NTP discharge [39]. In terms of regeneration, Vepřek et al used the plasma oxidation on the deactivated Hopcalite in order to establish $\mathrm{Cu}^{2+}$ at the catalyst surface at low temperature [40].

This work investigates the approach of adsorption plasma catalysis for the oxidation of toluene adsorbed on calcined Hopcalite at room temperature in a Hopcalite/glass beads packed bed dielectric barrier discharge (PBDBD) reactor. In addition to the oxidation of adsorbed toluene, this work also studies the regeneration of used Hopcalite after APC by NTP discharge by (i) adsorbing toluene from dry air on NTP regenerated Hopcalite, (ii) comparing the formation of by-products and catalytic activity during NTP discharge while using the fresh calcined and NTP regenerated Hopcalite and (iii) investigating and comparing the surface and bulk properties of fresh and NTP regenerated Hopcalite. The catalytic activity of different 
catalysts and the formation of by-products during the NTP discharge for the oxidation of adsorbed toluene are investigated using a Fourier-transform infrared (FTIR) spectrometer and a mass spectrometer. The stability of the catalysts in the NTP discharge is investigated by studying the surface and bulk properties of the catalysts using powder X-ray diffraction (XRD), scanning electron microscopy (SEM), nitrogen adsorption-desorption isotherms and X-ray photoelectron spectroscopy (XPS). The correlation between the physicochemical properties of the catalysts and their activity during adsorption plasma catalysis for the oxidation of adsorbed toluene has been established. A plausible reaction scheme for the decomposition of toluene in Hopcalite PBDBD reactor has been proposed.

\section{Experimental}

\subsection{Experimental set-up}

A general schematic of the experimental set-up used in this work is shown in Fig. S1. The set-up consists of three main parts (i) flue gas preparation; (ii) adsorption and/or non-thermal plasma reactor and (iii) gas analysis instrumentation. The initial concentration of toluene (Toluol $\geq 99.5 \%$, Carl Roth) in dry air (Alphagaz 1, Air Liquide) and the total gas flow rate are maintained at $500 \pm 10 \mathrm{ppm}$ and $0.2 \mathrm{~L} / \mathrm{min}$, respectively using a bubbler and a mass flow controller (MFC, El-flow ${ }^{\circledR}$, Bronkhorst). The relative humidity and the inlet temperature of the flue gas during the experiment were $3 \%$ and $25^{\circ} \mathrm{C}$, respectively. 


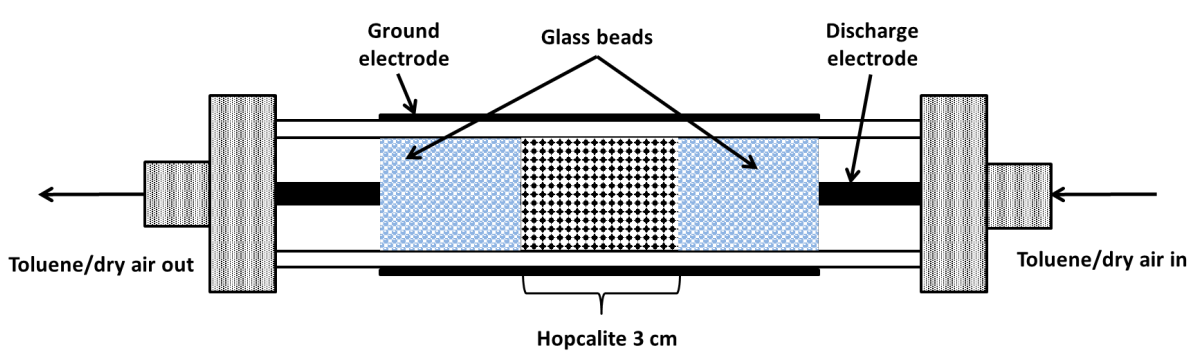

Fig. 1 Cross sectional view of Hopcalite \& glass beads packed bed dielectric barrier discharge (PBDBD) reactor

The schematic of the PBDBD reactor which is used as adsorption and NTP reactor is shown in Fig. 1. The dimensions of the DBD reactor are described in detail elsewhere [41]. The discharge gap is filled with $2 \mathrm{~g}$ of commercial Hopcalite (PureSphere) with particle sizes in the range of 200-300 $\mu \mathrm{m}$ and borosilicate glass beads (Sigma-Aldrich) of $3 \mathrm{~mm}$ diameter on both the sides of Hopcalite as shown in Fig. 1. The PBDBD plasma reactor was ignited with an ACpower supply of $50 \mathrm{kHz}$ frequency. The power injected in the plasma reactor is calculated by integrating the instantaneous voltage and current waveform averaged over four cycles. The calculation of the average power injected in the plasma reactor is explained in detail elsewhere [41].

The flue gas composition during different stages of the experiment such as adsorption, desorption by air and desorption by NTP discharge is investigated in-line with a FTIR spectrometer (Bruker, Tensor 27) and a quadrupole mass spectrometer (Hiden Analytical, HPR20 QIC R\&D). The FTIR is equipped with a DTGS (deuterated triglycine sulfate) detector and a gas cell with a $20 \mathrm{~cm}$ optical path length fitted with $\mathrm{ZnSe}$ windows. After reaching steady state conditions, the FTIR spectra averaged over 20 different samples are obtained with a 
resolution of $4 \mathrm{~cm}^{-1}$ and an aperture of $6 \mathrm{~mm}$. OPUS (Bruker) software is used to collect and analyze the obtained spectra. The concentrations of toluene and products such as $\mathrm{CO}$ and $\mathrm{CO}_{2}$ were measured quantitatively after calibration using standard gas mixtures; whereas the other by-products such as $\mathrm{NO}, \mathrm{NO}_{2}, \mathrm{~N}_{2} \mathrm{O}$ and $\mathrm{O}_{3}$ were analyzed qualitatively. The peak positions used for the identification of by-products and the wavenumber range used for the integration of area under the peak for the qualitative and quantitative comparison are given in the Table S1. The mass spectrometer is equipped with a dual Faraday (1-44 u) and electron multiplier detector (SEM, 45-150 u). MASoft PC (Hiden Analytical) software is used for collecting and analyzing data. The peaks are represented as bar lines over the corresponding mass (u). The measurements were also made in MID (multiple ion detection) mode for toluene (91 u, SEM detector), $\mathrm{CO}_{2}$ (44 u, Faraday detector) and benzene (78 u, SEM detector), which allows the collection of data as function of time for the preselected mass.

\subsection{Adsorption-plasma catalysis}

The schematic flow chart of the experimental steps of adsorption plasma catalysis for the abatement of toluene is shown in Fig. 2. The three steps involved in every cycle of the experimental flow are as follows: (i) adsorption of toluene from dry air on Hopcalite to quantify the adsorption capacity of Hopcalite, (ii) desorption by dry air to remove the reversibly adsorbed toluene and (iii) NTP discharge for total oxidation of adsorbed toluene and 
regeneration of used Hopcalite (also mentioned as NTP regenerated Hopcalite). Just before the first cycle, Hopcalite is calcined to remove the adsorbed carbonaceous compounds and moisture.

In this work, first, Hopcalite is packed in the DBD reactor as shown in the Fig. 1 after calcination at $300^{\circ} \mathrm{C}$ for 4 hours in $0.2 \mathrm{~L} / \mathrm{min}$ of dry air. Then, the dry air $(0.2 \mathrm{~L} / \mathrm{min})$ containing toluene $(500 \pm 10 \mathrm{ppm})$ is introduced in PBDBD reactor until the toluene the toluene concentration is nearly stable in the outlet. Then, dry air $(0.2 \mathrm{~L} / \mathrm{min})$ is flushed through the reactor to remove the reversibly adsorbed toluene. Finally, Hopcalite with irreversibly adsorbed toluene is exposed to a dry air $(0.2 \mathrm{~L} / \mathrm{min})$ NTP discharge $(44 \mathrm{~W})$. Then, the same sequence of steps except calcination such as adsorption, desorption by air and desorption by plasma are carried out on the NTP regenerated Hopcalite. The experimental parameters used during different steps of adsorption plasma catalysis such as calcination, adsorption, desorption by air and NTP discharge are summarized in Table. 1. 


\section{Calcination of Hopcalite}
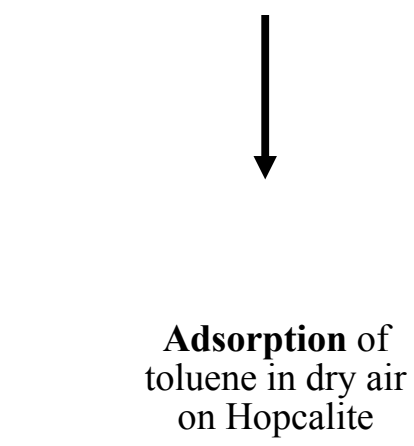

$\pi$ on Hopcalite

NTP discharge

- to oxidize irrversible adsorbed toluene air (to remove

- to regenerate Hopcalite reversibly adsorbed toluene)

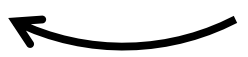

Fig. 2 Flow chart of experiment (one cycle) for adsorption plasma catalysis for abatement of toluene using PBDBD

reactor

The total amount of toluene adsorbed on Hopcalite (in $\mathrm{mmol} / \mathrm{g}$ ) is calculated from the breakthrough curve by integrating the area, as follows:

$$
[\text { Toluene }]_{\text {total adsorbed }}(\mathrm{mol} / \mathrm{g})=\int_{0}^{t} \frac{C(\mathrm{ppm}) f_{1}\left(\frac{\mathrm{L}}{\mathrm{min}}\right) d \mathrm{t}_{1}(\mathrm{~min})}{24.4\left(\frac{\mathrm{L}}{\mathrm{mol}}\right) \mathrm{m}(\mathrm{g})} \times 10^{-6}
$$

where $C$ is the difference between the inlet and outlet concentration of toluene, $f_{l}$ is the total flow rate during adsorption, $m$ is the mass of Hopcalite packed in PBDBD reactor and $t_{1}$ is the total adsorption time. The amount of toluene desorbed by dry air flushing (reversibly adsorbed toluene) and NTP discharge (unconverted irreversibly adsorbed toluene) is also calculated using equation (1) from the desorption curves. 
$[\text { Toluene }]_{\text {irreversibly adsorbed }}=[\text { Toluene }]_{\text {unconverted }}+[\text { Toluene }]_{\text {converted }}$

Thus, the difference between the 'total amount of toluene adsorbed' on Hopcalite and the toluene desorbed by dry air flushing (reversibly adsorbed toluene) gives the amount of 'irreversibly adsorbed toluene'. The difference between the amount of 'irreversibly adsorbed toluene' and the toluene desorbed by NTP discharge, i.e. unconverted toluene gives the amount of 'toluene converted during NTP discharge' (equation (2)).

The energy cost for remedying $1 \mathrm{~m}^{3}$ of polluted air $\left(\mathrm{EC}, \mathrm{kW} \cdot \mathrm{hm}^{-3}\right)$ and energy yield (EY, $\mathrm{g} / \mathrm{kWh}$ ) which is a measure of energy efficiency of the adsorption plasma catalysis process is calculated using the following equations:

$$
\begin{aligned}
& E C\left(k W \cdot \mathrm{hm}^{-3}\right)=\frac{P(\mathrm{~kW}) \times t_{2}(\mathrm{~min})}{F_{1}\left(\mathrm{~m}^{3} / \mathrm{h}\right) \times t_{1}(\mathrm{~min})} \\
& E Y(\mathrm{~g} / \mathrm{kWh})=\frac{\left[\text { Toluene }_{\text {total adsorbed }}(\mathrm{mol}) \times 92.14(\mathrm{~g} / \mathrm{mol}) \times 60\right.}{P(\mathrm{~kW}) \times t_{2}(\mathrm{~min})}
\end{aligned}
$$

where $P$ is the discharge power, $t_{1}$ and $t_{2}$ are the adsorption and discharge time respectively, $F_{l}$ is the total flow rate during adsorption.

The $\mathrm{CO}_{2}$ yield is defined as the ratio between the total amount of $\mathrm{CO}_{2}$ formed and the the theoretical amount of $\mathrm{CO}_{2}$ produced from the amount of toluene irreversibly adsorbed on Hopcalite $\left(\mathrm{C}_{7} \mathrm{H}_{8}^{*}+18 \mathrm{O}^{*} \rightarrow 7 \mathrm{CO}_{2}+4 \mathrm{H}_{2} \mathrm{O}\right)$. The $\mathrm{CO}_{2}$ selectivity is a parameter which reflects the percentage of converted toluene that has been converted to $\mathrm{CO}_{2}$. The $\mathrm{CO}_{2}$ yield and $\mathrm{CO}_{2}$ selectivity are calculated as following formula :

$$
\mathrm{CO}_{2 \text { yield }}(\%)=\frac{\left[\mathrm{CO}_{2}\right]_{\text {formed }}}{7 \times[\text { Toluene }]_{\text {irrevrsibly adsorbed }}} \times 100
$$


$\mathrm{CO}_{2 \text { selectivity }}(\%)=\frac{\left[\mathrm{CO}_{2}\right]_{\text {formed }}}{7 \times[\text { Toluene }]_{\text {converted }}} \times 100$

where $[\text { Toluene }]_{\text {converted }}$ is the amount of toluene irreversible adsorbed on Hopcalite converted by NTP discharge and $\left[\mathrm{CO}_{2}\right]_{\text {formed }}$ is the amount of $\mathrm{CO}_{2}$ formed during the NTP discharge.

Table 1 Experimental parameters used for adsorption plasma catalysis for abatement of toluene using Hopcalite $\&$ glass beads PBDBD reactor

\section{Calcination}

Gas

Dry air

Flow rate

$0.2 \mathrm{~L} / \mathrm{min}$

Temperature

$300^{\circ} \mathrm{C}$ for 4 hours

Heating rate

$1^{\circ} \mathrm{C} / \mathrm{min}$

Adsorption

\begin{tabular}{lc}
\hline Gas & Dry air \\
Flow rate & $0.2 \mathrm{~L} / \mathrm{min}$ \\
& \\
Toluene concentration & $500 \pm 10 \mathrm{ppm}$ \\
\hline
\end{tabular}

Desorption by air

\begin{tabular}{lc}
\hline Gas & Dry air \\
Flow rate & $0.2 \mathrm{~L} / \mathrm{min}$ \\
\hline
\end{tabular}

NTP discharge (for oxidation and regeneration) 
Gas

Flow rate

Applied power
Dry air

$0.2 \mathrm{~L} / \mathrm{min}$

The catalysts are labelled as fresh calcined Hopcalite, NTP (I) regenerated Hopcalite (after one cycle of adsorption-plasma catalysis) and NTP (II) regenerated Hopcalite (after two cycles of adsorption-plasma catalysis).

\subsection{Catalyst characterization}

Powder X-ray diffraction (PXRD) patterns of Hopcalite were collected using Thermo Scientific (ARL X'Tra) diffractometer, operated at $40 \mathrm{kV}, 30 \mathrm{~mA}$ using $\mathrm{Cu}-\mathrm{K} \alpha$ radiation $(\lambda=1.5406 \AA)$. The surface morphology of Hopcalite was imaged using a JEOL (JSM-6010 PLUS/LV) SEM. SEM images were acquired with an accelerating voltage, working distance and spot size of $7 \mathrm{kV}, 11$ and $30 \mathrm{~mm}$, respectively after coating the samples with a thin layer of gold using a sputter coater (JFC-1300 autofine coater, JEOL). Nitrogen adsorption-desorption measurements were carried out at the temperature of liquid nitrogen $\left(-196.0{ }^{\circ} \mathrm{C}\right)$ using a Micromeritics Tristar II 3020. Hopcalite samples were degassed at $120^{\circ} \mathrm{C}$ overnight prior to measurement. The specific surface area and pore volume were determined using the BrunauerEmmett-Teller (BET) method. The total pore volumes and pore sizes were calculated using the Broekhoff-de Boer method with the Frenkel-Halsey-Hill modification. The survey spectra and the detailed C 1s, O 1s, Mn 3s, Mn 2p and Cu 2p spectra of different Hopcalite samples were 
obtained using XPS analysis, in particular with a PHI Versaprobe II spectrometer equipped with a monochromatic $\mathrm{Al} \mathrm{K} \mathrm{K}_{\alpha} \mathrm{X}$-ray source $(\mathrm{h} v=1486.6 \mathrm{eV})$. The pass energies used for acquiring the survey and individual high resolution XPS spectra were $187.85 \mathrm{eV}$ and $23.5 \mathrm{eV}$, respectively. The atomic elemental composition was calculated from XPS survey spectra using Multipak software. The adventitious carbon at $285 \mathrm{eV}$ was used as internal standard and an iterated Shirley background was used to obtain the elemental composition.

\section{Results and Discussion}

\subsection{Adsorption of toluene on Hopcalite}

The breakthrough curve of toluene on fresh calcined Hopcalite surface and following dry air flushing is shown in Fig. 3. Quantification of this process indicates that the total adsorption capacity of Hopcalite is $0.25 \mathrm{mmol} / \mathrm{g}$. The amount of toluene desorbed by air (reversibly adsorbed toluene) which is quantified from the desorption curve is $0.05 \mathrm{mmol} / \mathrm{g}$, resulting in $0.20 \mathrm{mmol} / \mathrm{g}$ of toluene irreversibly adsorbed on fresh calcined Hopcalite surface. 


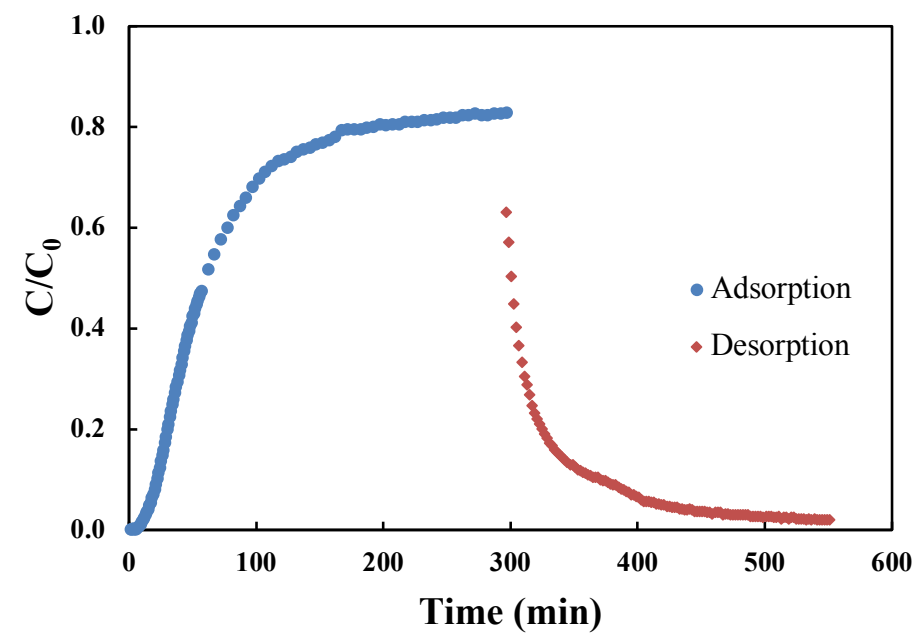

Fig. 3 Adsorption of toluene in dry air (initial concentration $=500 \mathrm{ppm}$; total flow rate $=0.2 \mathrm{~L} / \mathrm{min}$ ) and desorption of reversibly adsorbed toluene (total flow rate $=0.2 \mathrm{~L} / \mathrm{min}$ ) in fresh calcined Hopcalite \& glass beads packed bed DBD reactor

\subsection{Abatement of toluene adsorbed on Hopcalite}

As shown in Fig. 4, during the first few minutes of the NTP discharge, a significant amount of toluene was desorbed along with the formation of $\mathrm{CO}_{2}$. About $30 \%$ of irreversibly adsorbed toluene was desorbed by the NTP discharge but not converted. The remaining $0.14 \mathrm{mmol} / \mathrm{g}$ of toluene irreversibly adsorbed on Hopcalite is converted to other by-products during the NTP discharge. The total amount of $\mathrm{CO}_{2}$ formed during the NTP discharge was $0.84 \mathrm{mmol} / \mathrm{g}$ (quantified from the Fig. 4) which corresponds to a $\mathrm{CO}_{2}$ selectivity of $86 \%$

The FT-IR spectra of outlet gas from the PBDBD reactor during the NTP discharge at three different times (2, 15 and 30 minutes) are shown in the Fig. 5. The main products which were formed during the NTP regeneration of toluene saturated Hopcalite are $\mathrm{CO}_{2}$ and $\mathrm{H}_{2} \mathrm{O}$. There was no formation of $\mathrm{CO}$ as Hopcalite is proven to be the best catalyst for the oxidation of $\mathrm{CO}$ 
[34]. The mass spectra obtained in bar mode during the first two minutes of the NTP discharge are shown in Fig. S2 (a) and Fig. S2 (b) and they are measured using Faraday and SEM detector, respectively. From the mass spectrum, it is observed that there is formation of $\mathrm{CO}_{2}$ (mass $=44$ u, Fig. S2 (a)) and desorption of toluene (mass = 91, 92, 65, 63, 62, 51, 50 u, Fig. S2 (b)). The temporal evolution of partial pressure of mass corresponding to toluene (mass $=91 \mathrm{u}$ ), benzene $($ mass $=78 \mathrm{u})$ and $\mathrm{CO}_{2}($ mass $=44 \mathrm{u})$ measured in MID mode are shown in the Fig. S3. The temporal evolution of partial pressure corresponding to toluene and $\mathrm{CO}_{2}$ measured by mass spectrometer are in good agreement with that of the FTIR. The partial pressure corresponding to benzene (mass $=78 \mathrm{u}$ ) which is one order of magnitude lower than that of toluene suggests that the main carbon containing product formed during the decomposition of irreversibly adsorbed toluene is $\mathrm{CO}_{2}$.

The carbon balance plays an important role in determining the formation of the carbonaceous deposits or polymeric oil-like compounds, if any, on the catalysts, glass beads and in the inter wall of the reactor. The carbon balance of this process was determined by considering the amount of toluene adsorbed $(0.25 \mathrm{mmol} / \mathrm{g})$ on fresh calcined Hopcalite as $100 \%$ and it is shown in Fig. 6. During the desorption by flushing the dry air, $20 \%$ of carbon has been desorbed as toluene. During the NTP discharge of 60 minutes, there was a desorption of a significant amount of toluene and formation of $\mathrm{CO}_{2}$ which corresponds to $24 \%$ and $48 \%$ respectively. Using FT-IR and mass spectrometry, it can be concluded that there was no other 
carbon containing gaseous by-products were detected and thus resulting in the missing carbon mass balance of $8 \%$ which can be attributed to carbon deposited on the inner wall and packing glass beads of the PBDBD reactor, which was not visually observed.

Ozone was not detected in the outlet of the PBDBD reactor although NTP reactors produce ozone [41]. After 8 minutes of the NTP discharge, there was formation of $\mathrm{N}_{2} \mathrm{O}$ (Fig. 5 (b)). As the absolute quantification of $\mathrm{N}_{2} \mathrm{O}$ was not possible in this work, the temporal evolution of the integration area under the peak corresponding to the $\mathrm{N}_{2} \mathrm{O}$ bands $\left(2259-2223 \mathrm{~cm}^{-1}\right)$ is presented in Fig. 7 (a). In addition, the formation of $\mathrm{NO}_{2}$ was observed in the last 15 minutes of the NTP discharge and the temporal evolution of the integration area under the peak corresponds to $\mathrm{NO}_{2}$ $\left(1641-1619 \mathrm{~cm}^{-1}\right)$ is shown in Fig. 7 (b).

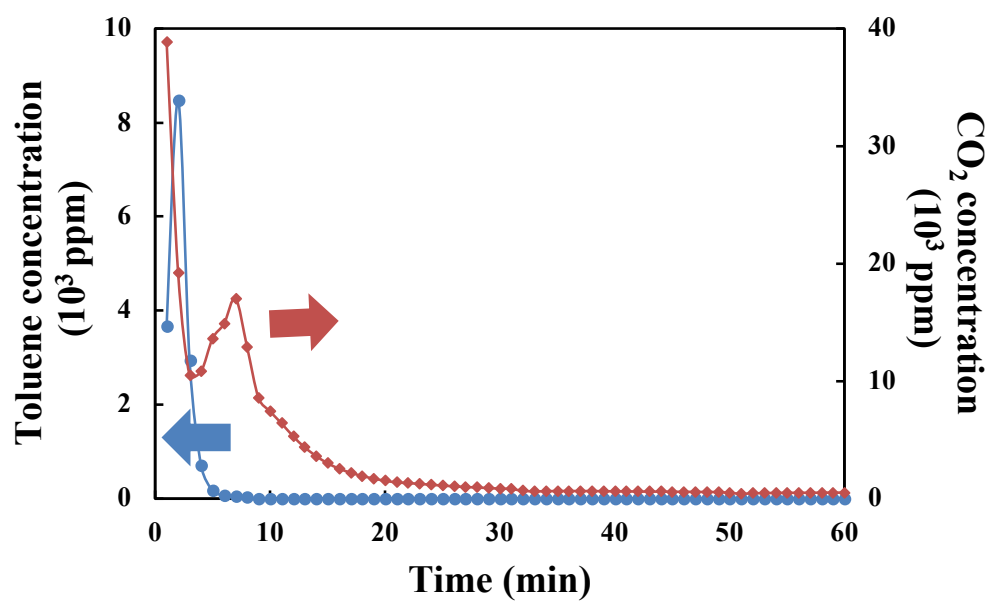

Fig. 4 Temporal evolution of concentration of toluene desorbed by NTP discharge and $\mathrm{CO}_{2}$ formation during NTP discharge at the outlet of the packed bed DBD reactor measured by FTIR (dry air, total flow rate $=0.2 \mathrm{~L} / \mathrm{min}$, discharge power $=44 \mathrm{~W}$ ) 

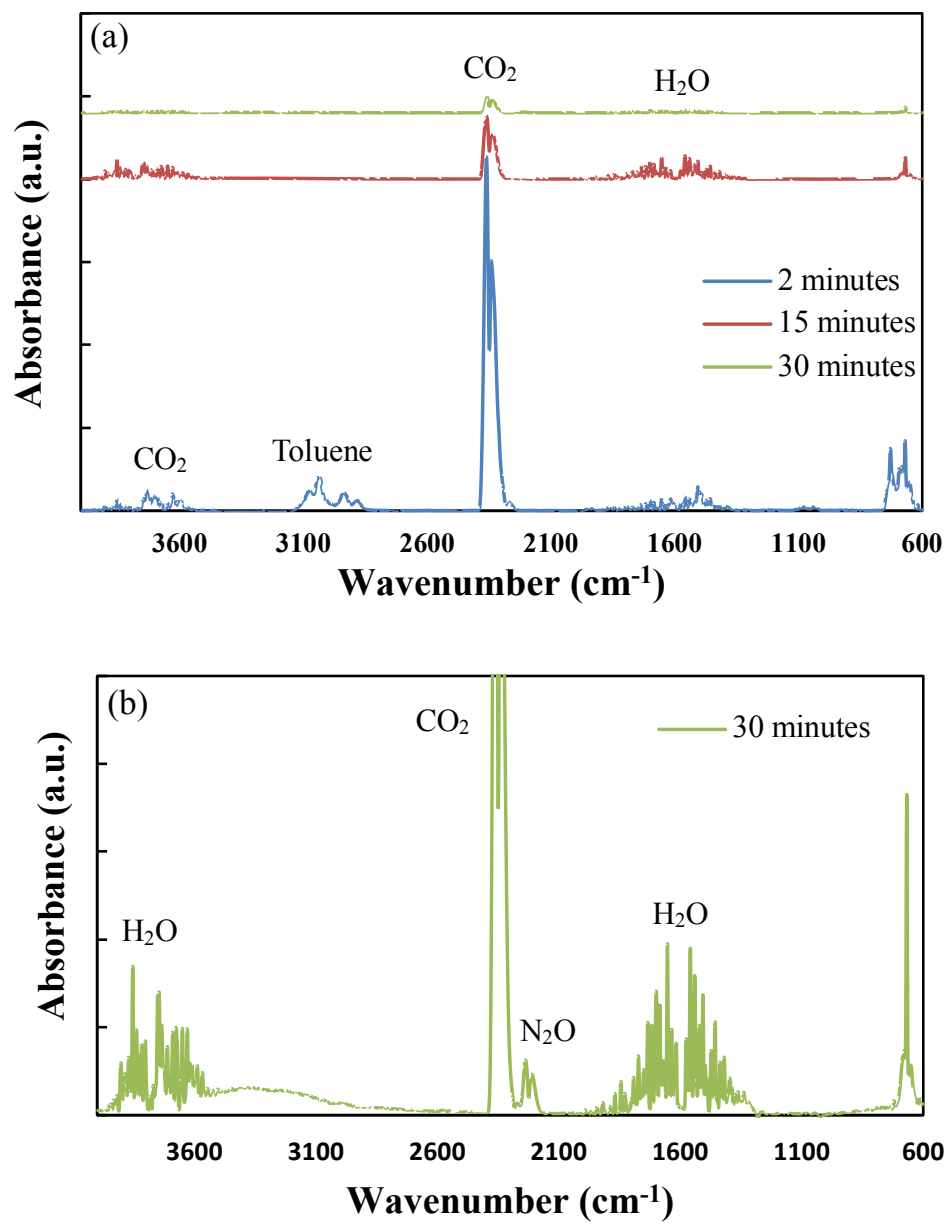

Fig. 5 FT-IR spectra of the outlet gas during NTP discharge (a) at three different time $(2,15$ and 30 minutes after NTP ignition) and (b) the zoom-in spectra to visualize bands corresponding to $\mathrm{N}_{2} \mathrm{O}$ after 30 minutes of NTP ignition in packed bed DBD reactor (dry air, total flow rate $=0.2 \mathrm{~L} / \mathrm{min}$, discharge power $=44 \mathrm{~W}$ ) 


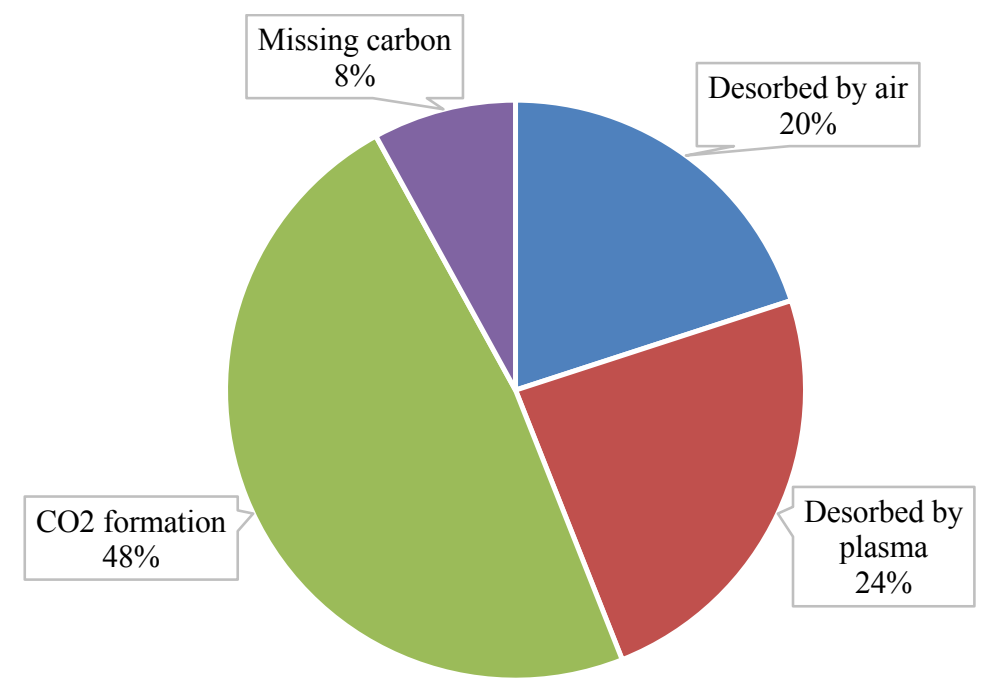

Fig. 6 Carbon balance of the toluene saturated fresh calcined Hopcalite during one cycle of adsorption plasma catalysis for abatement of toluene using PBDBD reactor
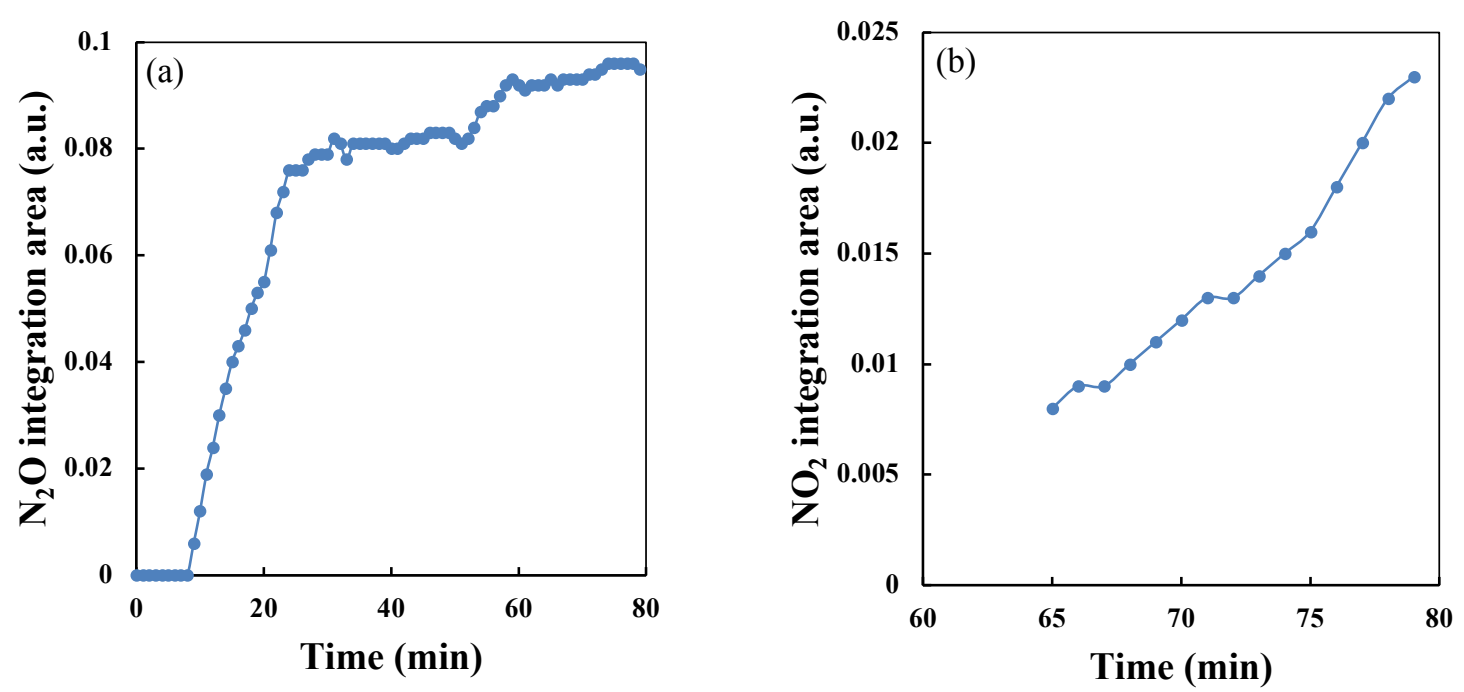

Fig. 7 Temporal evolution of the integration area under the peaks corresponding to different by-products such as

(a) $\mathrm{N}_{2} \mathrm{O}$ and (b) $\mathrm{NO}_{2}$ obtained during NTP discharge

\subsection{Regeneration of Hopcalite by NTP}

As already mentioned, in addition to the total oxidation of toluene adsorbed on Hopcalite by NTP discharge, it was also expected that the NTP discharge regenerates the used Hopcalite. 
The regeneration of used Hopcalite by NTP discharge can be determined by (i) adsorbing toluene on NTP regenerated Hopcalite and thus comparing the total amount of toluene adsorbed on fresh calcined and NTP regenerated Hopcalite, (ii) studying the oxidation ability of the NTP regenerated Hopcalite and comparing it's carbon balance and $\mathrm{CO}_{2}$ selectivity to that of the fresh calcined Hopcalite during NTP discharge and (iii) investigating the surface and bulk properties of both the fresh calcined and NTP regenerated Hopcalite.

\subsubsection{Adsorption of toluene on NTP (I) regenerated Hopcalite}

The breakthrough curves of toluene on fresh calcined and the NTP (I) regenerated Hopcalite surface are shown in Fig. 8. The total amount of toluene adsorbed on NTP (I) regenerated Hopcalite is $0.22 \mathrm{mmol} / \mathrm{g}$ (quantified by using equation (1)) and this is similar to that of the total amount of toluene adsorbed on fresh calcined Hopcalite. The total amount of toluene adsorbed, the amount afterwards desorbed by dry air and the amount irreversibly adsorbed toluene on the fresh calcined and NTP (I) regenerated Hopcalite are shown in Table 2. As it can been seen, the ratio of the irreversibly adsorbed toluene to the total adsorbed toluene on the NTP (I) regenerated Hopcalite (0.82) is similar to that of fresh calcined Hopcalite $(0.80)$, suggesting a good regeneration of the used Hopcalite by NTP discharge in terms of adsorption capacity. 


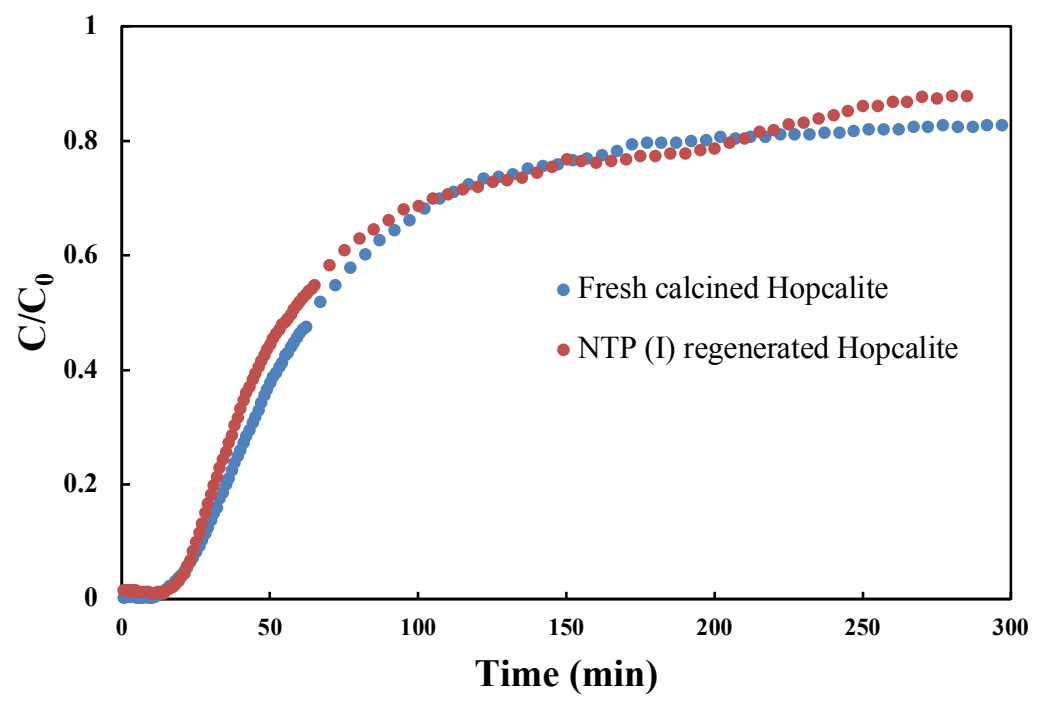

Fig. 8 Adsorption of toluene in dry air on fresh calcined and NTP (I) regenerated Hopcalite in Hopcalite \& glass beads PBDBD reactor (initial concentration $=500 \mathrm{ppm}$; total flow rate $=0.2 \mathrm{~L} / \mathrm{min}$ )

\subsubsection{Oxidation ability of NTP (I) regenerated Hopcalite}

The temporal evolution of the toluene concentration desorbed by the NTP discharge and the formation of $\mathrm{CO}_{2}$ during the NTP discharge for both the fresh calcined and NTP (I) regenerated Hopcalite are shown in Fig. 9 (a) and Fig. 9 (b), respectively. These temporal profiles were integrated in order to get the amount of unconverted toluene desorbed by NTP and $\mathrm{CO}_{2}$ formed during the NTP discharge (using equation (1)) and the results are reported in Table 2. The amount of unconverted toluene desorbed by NTP discharge was $0.06 \mathrm{mmol} / \mathrm{g}$ for both the fresh calcined and NTP (I) regenerated Hopcalite. This results in $0.14 \mathrm{mmol} / \mathrm{g}$ and $0.12 \mathrm{mmol} / \mathrm{g}$ of converted toluene for fresh calcined and NTP (I) regenerated Hopcalite respectively. It has been mentioned in the previous section that the only carbon containing gaseous by-product detected by FTIR and mass spectrometer during the NTP discharge is $\mathrm{CO}_{2}$. The total amounts of $\mathrm{CO}_{2}$ 
formed during the NTP discharge are $0.84 \mathrm{mmol} / \mathrm{g}$ and $0.78 \mathrm{mmol} / \mathrm{g}$ for the fresh calcined and NTP (I) regenerated Hopcalite, respectively. The $\mathrm{CO}_{2}$ selectivity of this process using fresh calcined and NTP (I) regenerated Hopcalite are $86 \%$ and $93 \%$, respectively. The higher $\mathrm{CO}_{2}$ selectivity of NTP (I) regenerated Hopcalite despite the lower amount of $\mathrm{CO}_{2}$ produced while using NTP (I) regenerated Hopcalite when compared to that of the fresh calcined Hopcalite is explained partly by the lesser amount of toluene adsorbed on NTP (I) regenerated Hopcalite.
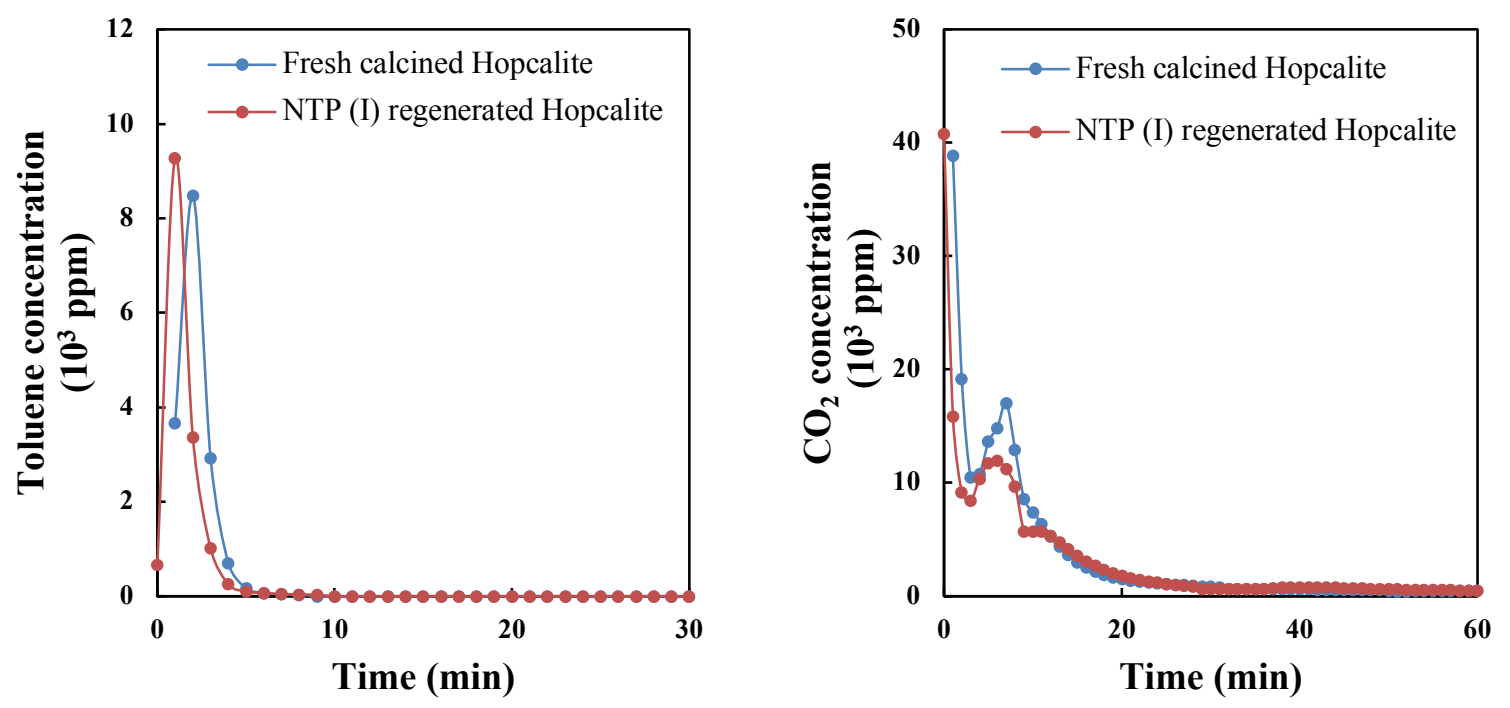

Fig. 9 Temporal evolution of concentration of (a) NTP desorbed toluene and (b) $\mathrm{CO}_{2}$ formation during NTP discharge at the outlet of the packed bed DBD reactor for fresh calcined Hopcalite and NTP (I) regenerated Hopcalite (dry air, total flow rate $=0.2 \mathrm{~L} / \mathrm{min}$, discharge power $=44 \mathrm{~W}$ )

Table 2 Amount of toluene adsorbed, desorbed by air and NTP discharge, $\mathrm{CO}_{2}$ formation during NTP discharge energy cost and energy yield for fresh calcined and NTP (I) regenerated Hopcalite in Hopcalite \& glass beads

PBDBD reactor 


\begin{tabular}{lcc} 
Total adsorbed toluene (mmol/g) & 0.25 & 0.22 \\
Toluene desorbed by air (mmol/g) & 0.05 & 0.04 \\
Irreversibly adsorbed toluene (after air) & 0.20 & 0.18 \\
(mmol/g) & & \\
Unconverted toluene desorbed by NTP discharge & 0.06 & 0.06 \\
(mmol/g) & & \\
Converted toluene (during NTP discharge) & 0.14 & 0.12 \\
& & \\
(mmol/g) & & \\
CO 2 formation (mmol/g) & 0.84 & 0.78 \\
Energy cost $\left(\mathrm{kWhm}{ }^{-3}\right)$ & 0.74 & 0.77 \\
Energy yield $(\mathrm{g} / \mathrm{kWh})$ & & \\
\hline
\end{tabular}

The carbon balance of the process while using fresh calcined and NTP (I) regenerated Hopcalite is shown in Fig. 10. The carbon balance is calculated considering the amount of toluene irreversibly adsorbed on fresh calcined $(0.20 \mathrm{mmol} / \mathrm{g})$ and NTP (I) regenerated $(0.18$ $\mathrm{mmol} / \mathrm{g}$ ) as $100 \%$. As shown in Fig. 10, the total amount of toluene desorbed by NTP discharge for NTP (I) regenerated Hopcalite (33\%) is higher than that of the fresh calcined Hopcalite (30\%). The amount of carbon that is irreversibly adsorbed on Hopcalite which is converted to $\mathrm{CO}_{2}\left(\mathrm{CO}_{2}\right.$ yield $)$ is higher for the NTP (I) regenerated Hopcalite. Also, it is evident from Fig. 10 that the amount of missing carbon while using NTP (I) regenerated Hopcalite is 
approximately two times less than that of the fresh calcined Hopcalite. Thus, less converted toluene, more $\mathrm{CO}_{2}$ yield and less missing carbon while using NTP (I) regenerated Hopcalite results in higher $\mathrm{CO}_{2}$ selectivity, suggesting that the oxidization ability of the NTP (I) regenerated Hopcalite is slightly better than that of the fresh calcined Hopcalite. The $\mathrm{CO}_{2}$ yield and $\mathrm{CO}_{2}$ selectivity during the NTP discharge for the oxidization of irreversibly adsorbed toluene calculated using equation (5) and equation (6), respectively are shown in Table 3.

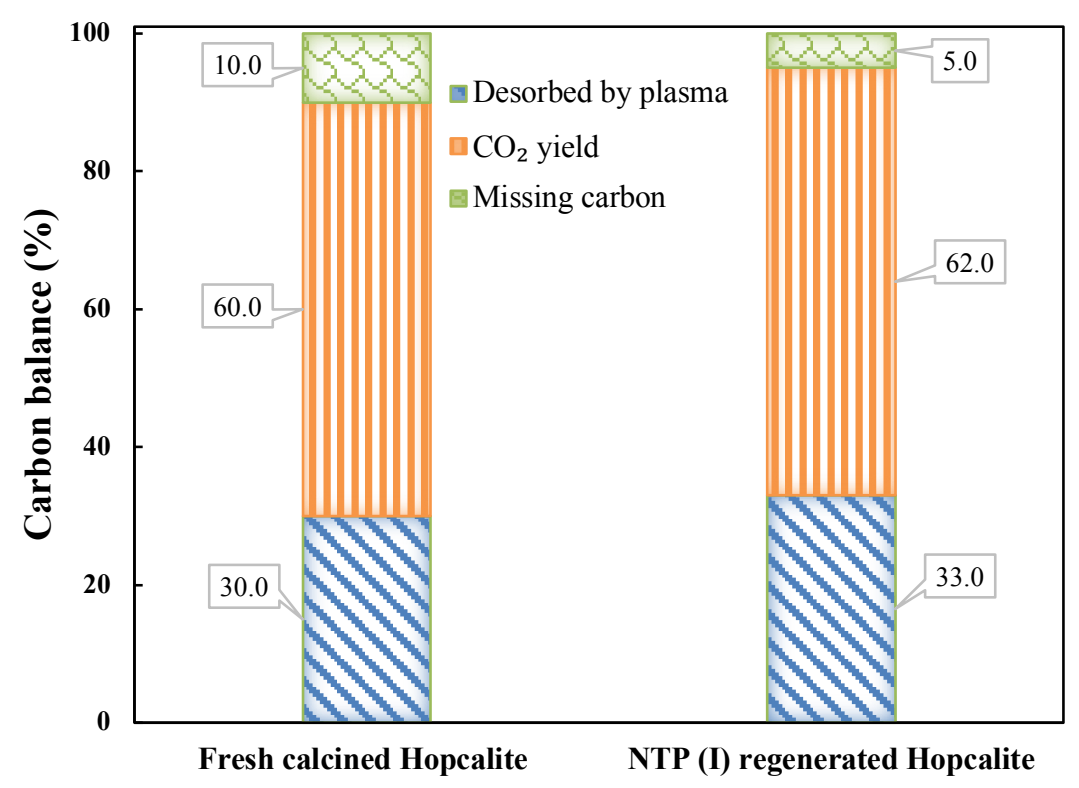

Fig. 10 Carbon balance for the adsorption plasma catalytic abatement of toluene adsorbed on fresh calcined and NTP (I) regenerated Hopcalite in Hopcalite \& glass beads PBDBD reactor 
Table $3 \mathrm{CO}_{2}$ yield and $\mathrm{CO}_{2}$ selectivity during the NTP discharge using fresh calcined and NTP (I) regenerated

\begin{tabular}{ccc} 
& Hopcalite & \\
Catalyst & Fresh calcined & NTP (I) regenerated \\
& Hopcalite & Hopcalite \\
\cline { 2 - 3 } & & $(\%)$ \\
$\mathrm{CO}_{2}$ yield & 60 & 62 \\
$\mathrm{CO}_{2}$ selectivity & & \\
\hline
\end{tabular}

The regeneration of the activity $\left(\mathrm{S}_{\mathrm{CO} 2}\right)$ of the used Hopcalite when compared to the fresh calcined by non-thermal plasma is comparable to the work reported in literature. Kireev et al [42] developed a procedure for the activation of the deactivated Hopcalite using $\mathrm{CaO}$ as a binder for the preparation of the extrudes followed by washing, drying and calcination. The activity of the reactivated catalyst for ozone decomposition was 0.81 to 0.85 when compared to the fresh catalyst $(0.93)$ at $200{ }^{\circ} \mathrm{C}$.

\subsubsection{Surface and bulk properties of fresh calcined and NTP regenerated Hopcalite}

The surface and the bulk properties of fresh calcined and NTP regenerated Hopcalite such as crystallinity, surface morphology, specific surface area $\left(\mathrm{S}_{\mathrm{BET}}\right)$ and pore size and surface elemental composition, the oxidation state of metals and the relative amount oxygen species are measured and estimated by XRD, SEM, $\mathrm{N}_{2}$ - adsorption desorption isotherms and XPS, respectively. Vepřek et al [40] investigated the deactivation of Hopcalite in detail and reported 
that the following changes in the catalytic properties are associated with the deactivation of Hopcalite: (i) segregation of $\mathrm{K}$ to the surface of Hopcalite, (ii) surface enrichment of Cu relative to $\mathrm{Mn}$, (iii) formation of spinel phase and (iv) transformation of $\mathrm{Cu}^{2+} \rightarrow \mathrm{Cu}^{+}$and $\mathrm{Mn}^{3+} \rightarrow \mathrm{Mn}^{4+}$. The catalytic properties of fresh calcined and NTP regenerated Hopcalite are thus compared to establish the effect of the NTP discharge on Hopcalite. In order to understand the relationship between the properties of Hopcalite and their performance during toluene adsorption (total, reversible and irreversible) and NTP oxidation of irreversible adsorbed toluene, the surface and bulk properties are measured on fresh calcined Hopcalite, NTP (I) regenerated Hopcalite and NTP (II) regenerated Hopcalite.

The X-ray diffraction patterns of the fresh calcined, NTP (I) regenerated and NTP (II) regenerated Hopcalite are shown in Fig. 11. The XRD pattern of the fresh calcined Hopcalite is characteristics of an amorphous material. New diffraction peaks have been detected in the XRD pattern of the NTP (I) regenerated Hopcalite located at $36.2^{\circ}, 32.2^{\circ}$ and $29.1^{\circ}$ which match with those characteristics of the (211), (103) and (112) planes of tetragonal $\mathrm{Mn}_{3} \mathrm{O}_{4}$ (JCPDS 04-0071841). Such peaks are observed on the NTP (II) regenerated Hopcalite. Consequently, NTP discharge affects the structure and crystallinity of Hopcalite after the first cycle while the characteristics of the material do not significantly change after the second NTP treatment. 


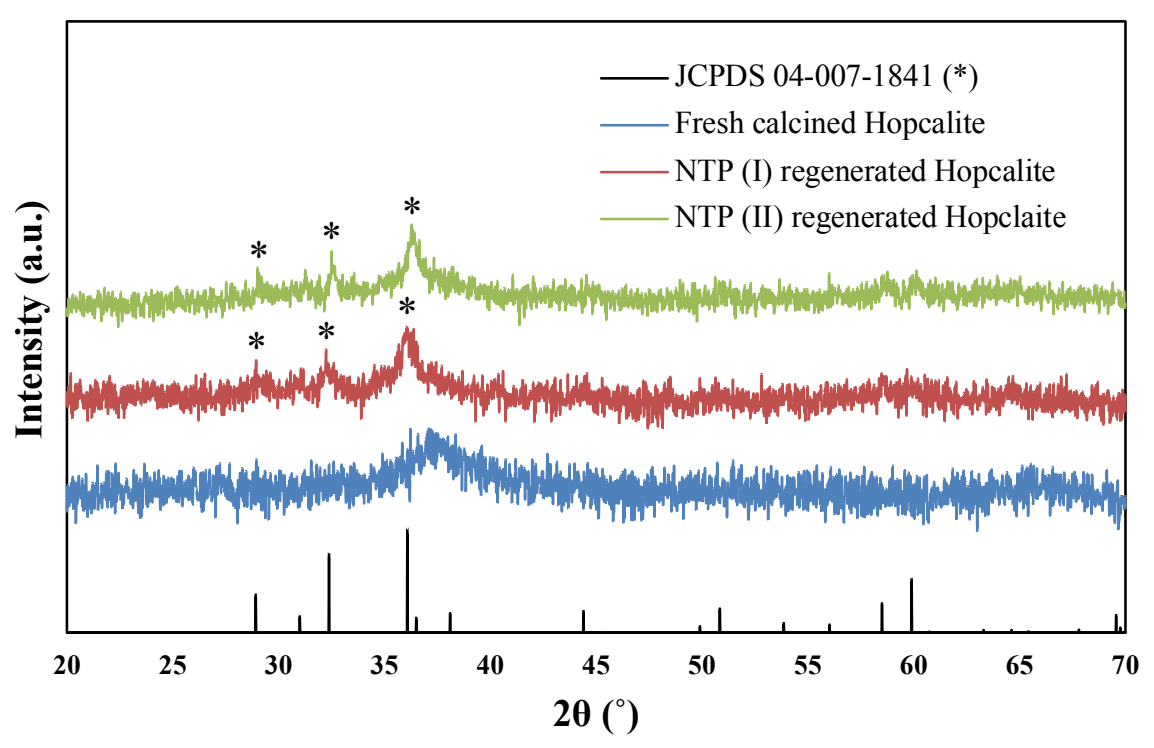

Fig. 11 XRD patterns of fresh calcined, NTP (I) regenerated and NTP (II) regenerated Hopcalite

The SEM images of the fresh and NTP (II) regenerated Hopcalite (Fig. S4) clearly show that there is no agglomeration or sintering occurring on the NTP regenerated Hopcalite in comparison to that of the fresh Hopcalite. The textural properties of the fresh calcined, NTP (I) regenerated and NTP (II) regenerated Hopcalite are listed in Table 4. The $\mathrm{N}_{2}$ adsorptiondesorption isotherms of fresh calcined and NTP (II) regenerated Hopcalite (Fig. S5) illustrate a type IV isotherm with a hysteresis loop in the relative pressure range $\left(\mathrm{P} / \mathrm{P}_{0}\right)$ of $0.45-1.00$ and 0.55-1.00 for fresh calcined and NTP (II) regenerated Hopcalite, respectively, indicating the mesoporosity of the material. The specific surface area and pore volume of fresh calcined and NTP (II) regenerated Hopcalite are $215 \mathrm{~m}^{2} / \mathrm{g}$ and $94 \mathrm{~m}^{2} / \mathrm{g}$, respectively and $0.36 \mathrm{~cm}^{3} / \mathrm{g}$ and 0.18 $\mathrm{cm}^{3} / \mathrm{g}$, respectively. The $\mathrm{S}_{\mathrm{BET}}$ and pore volume of the NTP (I) regenerated Hopcalite is approximately two times lower than that of the fresh calcined Hopcalite. On contrary, the total amount of toluene adsorbed per unit area of the NTP (I) regenerated Hopcalite is two times 
higher than that of the fresh calcined Hopcalite which is calculated using the equation given below (Table 4), suggesting that the specific surface of Hopcalite is not main determining factor for toluene adsorption. Also, it is noted that the pore size is higher in the NTP regenerated Hopcalite when compared to the fresh calcined Hopcalite.

Toluene adsorbed per unit area $\left(\frac{\mu m o l}{m^{2}}\right)=\frac{\text { Total adsorbed toluene }\left(\frac{m m o l}{g}\right)}{S_{B E T}\left(\frac{m^{2}}{g}\right)} \times 10^{3}$

Table 4 Surface properties of fresh calcined and plasma regenerated Hopcalite

Fresh calcined NTP (I) regenerated NTP (II) regenerated

Hopcalite Hopcalite Hopcalite

\begin{tabular}{|c|c|c|c|}
\hline BET surface area $\left(\mathrm{m}^{2} / \mathrm{g}\right)$ & 215 & 99 & 94 \\
\hline Pore size $(\AA)$ & 61 & 72 & 69 \\
\hline Pore volume $\left(\mathrm{cm}^{3} / \mathrm{g}\right)$ & 0.36 & 0.19 & 0.18 \\
\hline Total adsorbed toluene $(\mathrm{mmol} / \mathrm{g})$ & 0.25 & 0.22 & -- \\
\hline Amount of toluene adsorbed per unit area & 1.16 & 2.21 & -- \\
\hline
\end{tabular}

The elemental composition of fresh calcined and NTP (II) regenerated Hopcalite obtained from the survey spectra (Fig. S6) of XPS is shown in Fig. 12 and Table S2. The atomic percent of $\mathrm{Cu}(0.3 \%$ higher $)$ and $\mathrm{K}(0.8 \%$ higher $)$ in NTP (II) regenerated Hopcalite are marginally higher than fresh calcined Hopcalite. This indicates that there is no relative surface enrichment of $\mathrm{Cu}$ and a slight surface segregation of $\mathrm{K}$ on NTP regenerated Hopcalite. There is no 
comparable difference in the atomic percent of Mn in fresh calcined and NTP (II) regenerated Hopcalite. The ratio $\mathrm{Cu} / \mathrm{Mn}$ of the NTP (II) regenerated Hopcalite is only very marginally higher when compared to the fresh calcined Hopcalite, suggesting that there is no surface enrichment of $\mathrm{Cu}$ relative to $\mathrm{Mn}$. The ratio $\mathrm{K} / \mathrm{Mn}$ has increased from 0.09 (fresh calcined Hopcalite) to 0.12 (NTP (II) regenerated Hopcalite) and suggests that there is slight aggregation of $\mathrm{K}$ on the surface of Hopcalite after being exposed to a NTP discharge. The increase in the ratio of $\mathrm{K} / \mathrm{Mn}$ is very small when compared to the data which has been already reported resulting in the deactivation of the $\mathrm{Cu}-\mathrm{Mn}$ oxide based catalysts [43]. This is in agreement with the results obtained in this work that the catalytic activity Hopcalite is maintained after being exposed to the NTP discharge.

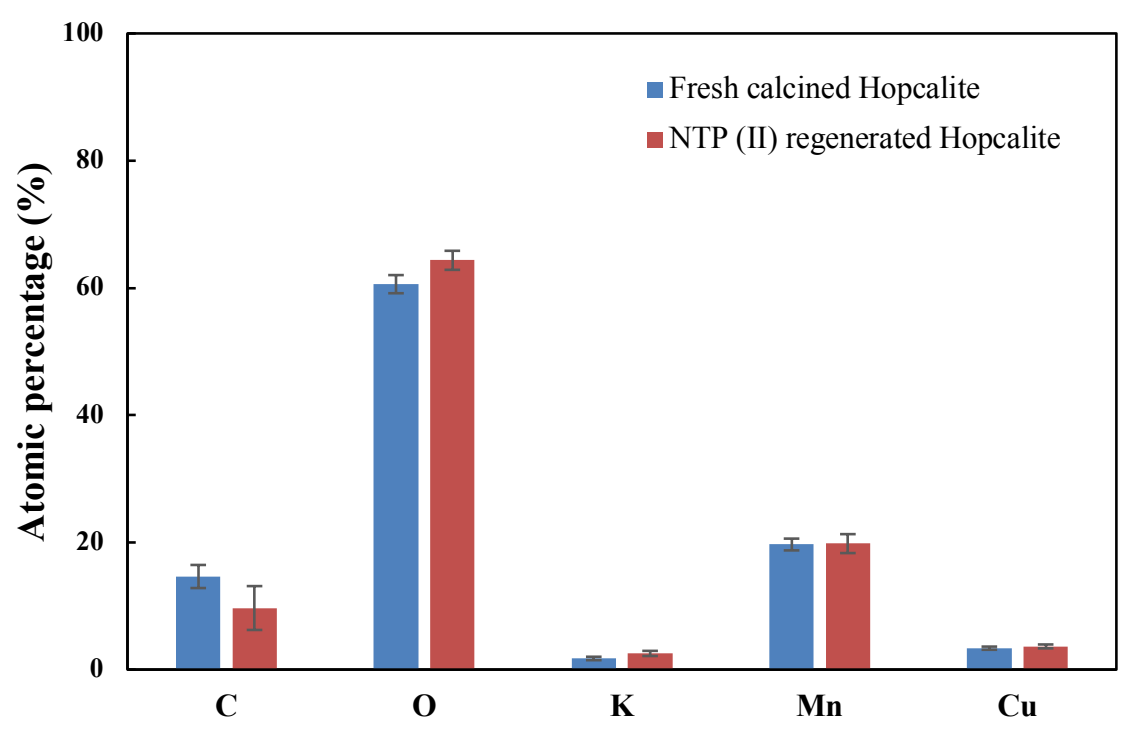

Fig. 12 Surface elemental composition of fresh calcined and NTP(II) regenerated Hopcalite as analyzed from XPS survey spectra 
The high-resolution detailed spectra of fresh calcined and NTP (II) regenerated Hopcalite are shown in the Fig. 13 and Fig. S7. The nature of oxygen atoms bound to metal in Hopcalite and their relative abundance plays an important role in its catalytic activity for hydrocarbon oxidation [44]. The O 1s detailed spectra of fresh calcined and NTP (II) regenerated Hopcalite are shown in Fig. 13 (a). The three kinds of oxygen species that are identified in these samples are lattice oxygen $\left(\mathrm{O}_{\mathrm{l}}, 529.7-530.2 \mathrm{eV}\right)$, adsorbed oxygen $\left(\mathrm{O}_{\mathrm{a}}, 531.3-532 \mathrm{eV}\right)$ and adsorbed water molecule $(\sim 533.4 \mathrm{eV})$. The adsorbed oxygen species are more mobile than the lattice oxygen and they play an important role in the oxidation of hydrocarbons at low temperature [45]. The peak position and abundance of the lattice oxygen, adsorbed oxygen and adsorbed water and the ratio of adsorbed oxygen to lattice oxygen $\left(\mathrm{O}_{\mathrm{a}} / \mathrm{O}_{1}\right)$ on fresh calcined and NTP (II) regenerated Hopcalite are listed in Table 5. The ratio of $\mathrm{O}_{a} / \mathrm{O}_{1}$ for NTP (II) regenerated Hopcalite is higher than that of the fresh calcined Hopcalite. This explains the good catalytic activity and higher $\mathrm{CO}_{2}$ selectivity of NTP regenerated Hopcalite despite its reduced $\mathrm{S}_{\mathrm{BET}}$.

The oxidation state of Mn has been determined from the Mn 3s splitting originating from the exchange coupling between the 3 s hole and the $3 \mathrm{~d}$ electrons. It is already known from the literature that the splitting energy $(\Delta \mathrm{E})$ for $\mathrm{Mn}^{4+}, \mathrm{Mn}^{3+}$ and $\mathrm{Mn}^{2+}$ are $4.5 \mathrm{eV}, 5.5 \mathrm{eV}$ and $6 \mathrm{eV}$, respectively [46]. The Mn 3s spectra of the fresh calcined and NTP (II) regenerated Hopcalite are shown in the Fig. 13 (b). The splitting energy of the fresh calcined and NTP (II) regenerated Hopcalite are $5.1 \mathrm{eV}$ and $5.2 \mathrm{eV}$, respectively, suggesting that the oxidation state of $\mathrm{Mn}$ in 
Hopcalite is predominantly $\mathrm{Mn}^{3+}$ and there is no noticeable change in the oxidation state of $\mathrm{Mn}$ after NTP regeneration.
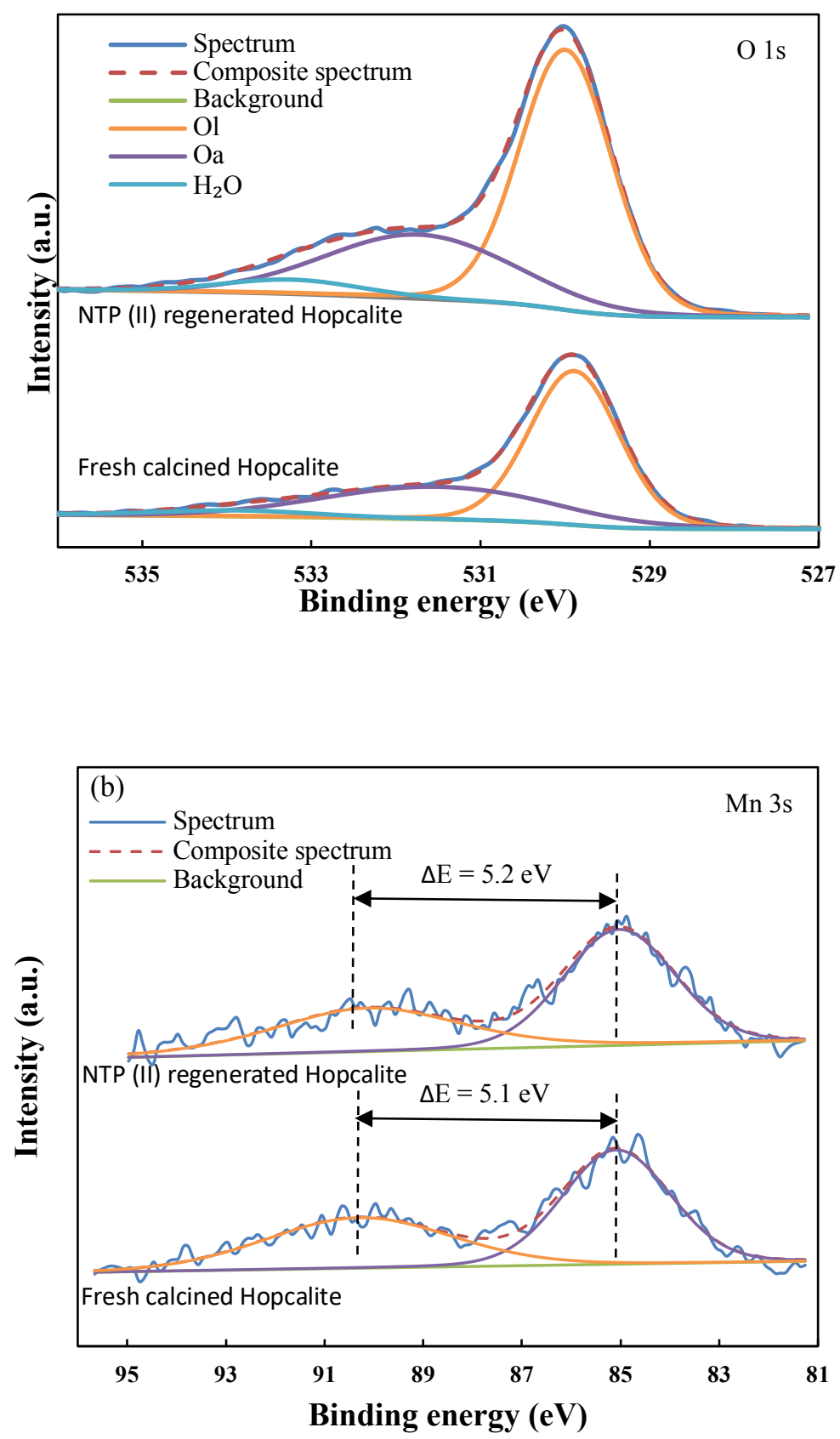

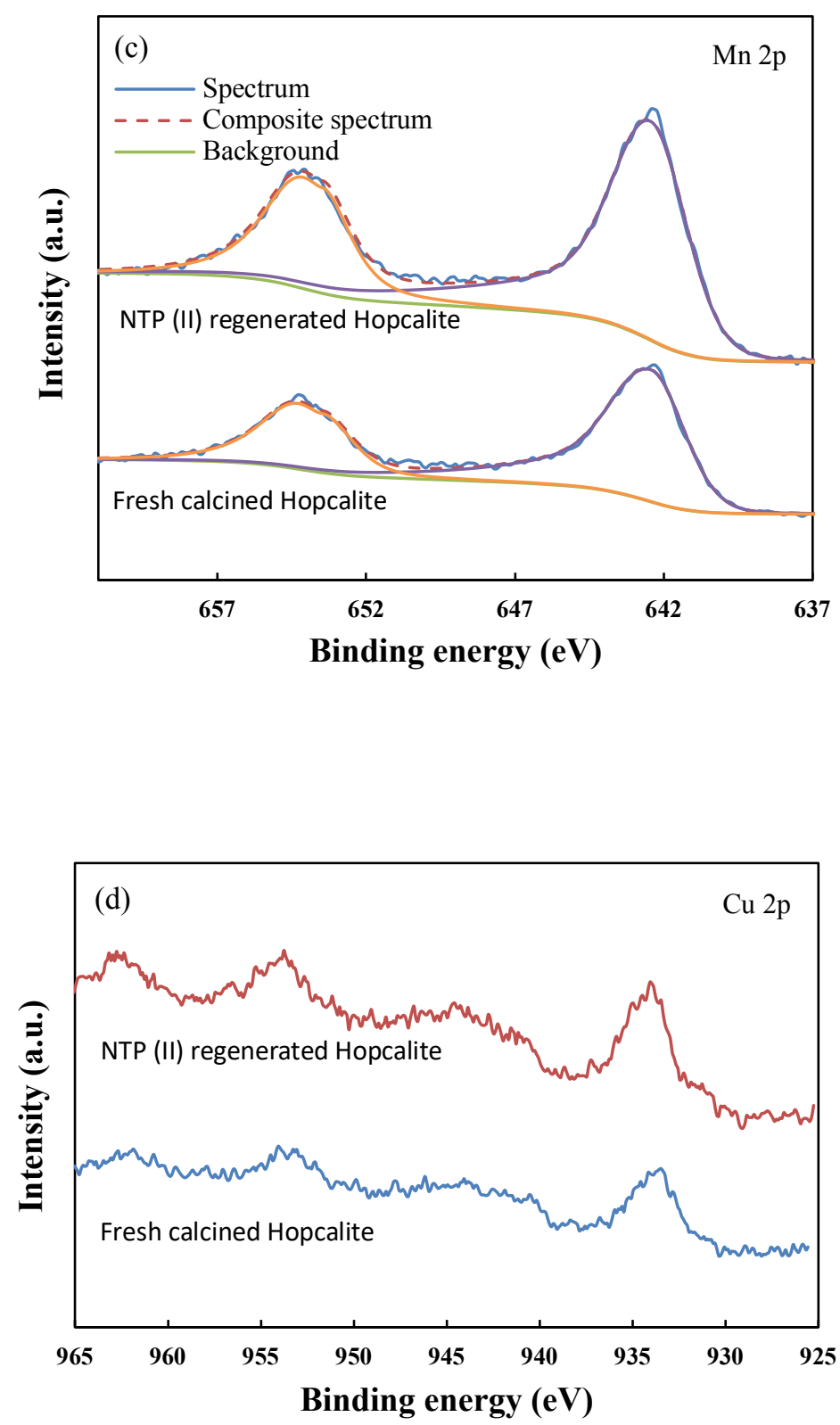

Fig. 13 XPS detailed spectra of (a) O 1s, (b) Mn 3s, (c) Mn 2p and (d) Cu 2p for fresh calcined and NTP (II) regenerated Hopcalite 
Table 5 Abundance of oxygen species obtained from XPS detailed spectra

\begin{tabular}{|c|c|c|c|c|c|c|c|}
\hline & \multicolumn{2}{|l|}{$\mathrm{O}_{1}$} & \multicolumn{2}{|l|}{$\mathrm{O}_{\mathrm{a}}$} & \multicolumn{2}{|l|}{$\mathrm{H}_{2} \mathrm{O}$} & \multirow[t]{3}{*}{$\mathrm{O}_{\mathrm{a}} / \mathrm{Ol}$} \\
\hline & Peak position & Atomic & Peak position & Atomic & Peak position & Atomic & \\
\hline & $(\mathrm{eV})$ & $\%$ & $(\mathrm{eV})$ & $\%$ & $(\mathrm{eV})$ & $\%$ & \\
\hline \multicolumn{8}{|l|}{ Fresh } \\
\hline & $529.9 \pm 0.1$ & 68.0 & $531.5 \pm 0.1$ & 22.0 & $533.4 \pm 0.3$ & 10.0 & 0.32 \\
\hline \multicolumn{8}{|l|}{ calcined } \\
\hline \multicolumn{8}{|l|}{ NTP (II) } \\
\hline & $529.9 \pm 0.1$ & 61.1 & $531.6 \pm 0.2$ & 32.1 & $533.2 \pm 0.3$ & 6.8 & 0.53 \\
\hline regenerated & & & & & & & \\
\hline
\end{tabular}

Table 6 Binding energies of Mn 2p and $\mathrm{Cu} 2 \mathrm{p}$ peaks obtained from XPS detailed spectra

\begin{tabular}{|c|c|c|c|}
\hline & \multicolumn{3}{|c|}{ Peak position (eV) } \\
\hline & $\operatorname{Mn} 2 p_{3 / 2}$ & $\operatorname{Mn} 2 p_{1 / 2}$ & $\mathrm{Cu} 2 \mathrm{p}_{3 / 2}$ \\
\hline Fresh calcined Hopcalite & $642.3 \pm 0.1$ & $653.4 \pm 0.1$ & $933.8 \pm 0.1$ \\
\hline NTP (II) regenerated & $642.5 \pm 0.1$ & $653.5 \pm 0.1$ & $933.9 \pm 0.1$ \\
\hline Hopcalite & & & \\
\hline
\end{tabular}

The peak position of $\mathrm{Mn} 2 \mathrm{p}_{3 / 2}, \mathrm{Mn} 2 \mathrm{p}_{1 / 2}$ and $\mathrm{Cu} 2 \mathrm{p}_{3 / 2}$ of the fresh and NTP (II) regenerated Hopcalite obtained from the high resolution XPS spectra are listed in the Table. 6. These peak positions remain the same suggesting that these species are not affected by the overall process or effectively regenerated by NTP discharge. The binding energy of $\mathrm{Cu} 2 \mathrm{p}_{3 / 2}(933.8 \mathrm{eV})$ shows the presence of copper (II) oxidation which is common for the binary copper manganese oxide. 
The presence of the shake-up peaks in $\mathrm{Cu} 2 \mathrm{p}$ spectra indicated that $\mathrm{Cu}^{2+}$ phase is present predominantly on the surface of the catalyst. Veprek et al reported that thermally deactivated Hopcalite $(>773 \mathrm{~K})$ was regenerated by a low pressure $(1.3 \mathrm{mbar}) \mathrm{O}_{2}$ glow discharge through $\mathrm{Cu}^{1+}$ to $\mathrm{Cu}^{2+}$ conversion; whereas, in this work, the used Hopcalite was regenerated by air NTP at atmospheric pressure.

\subsection{Reaction scheme of toluene oxidation in Hopcalite PBDBD}

During the NTP discharge, the proposed reaction pathway can be divided into two parts, (i) the part of toluene which is desorbed resulting in the reaction in gas phase and (ii) the toluene remained adsorbed results in the reaction at the catalyst surface. The former involves the direct degradation of desorbed toluene by electron collision followed by the reaction with other short life active species (such as $\mathrm{N}^{+}, \mathrm{N}_{2}{ }^{+}, \mathrm{O}^{+}$and $\mathrm{O}_{2}{ }^{+}$). The latter involves the total oxidation of adsorbed toluene by Hopcalite which is often described by Mars and Van Krevelen (MVK) mechanism. A plausible degradation route for desorbed toluene in gas phase and adsorbed toluene on the catalyst surface is illustrated in Fig 14. Among the main decomposition gas phase by-products of toluene oxidation in glass beads DBD reactor (such as $\mathrm{CO}_{2}, \mathrm{CO}, \mathrm{N}_{2} \mathrm{O}$ and ozone) which has been already reported [41], $\mathrm{CO}_{2}$ and $\mathrm{N}_{2} \mathrm{O}$ are present in Hopcalite/glass beads PBDBD. However, the oxidation of $\mathrm{CO}$ and decomposition of ozone in the presence of Hopcalite can be elucidated by MVK mechanism. 


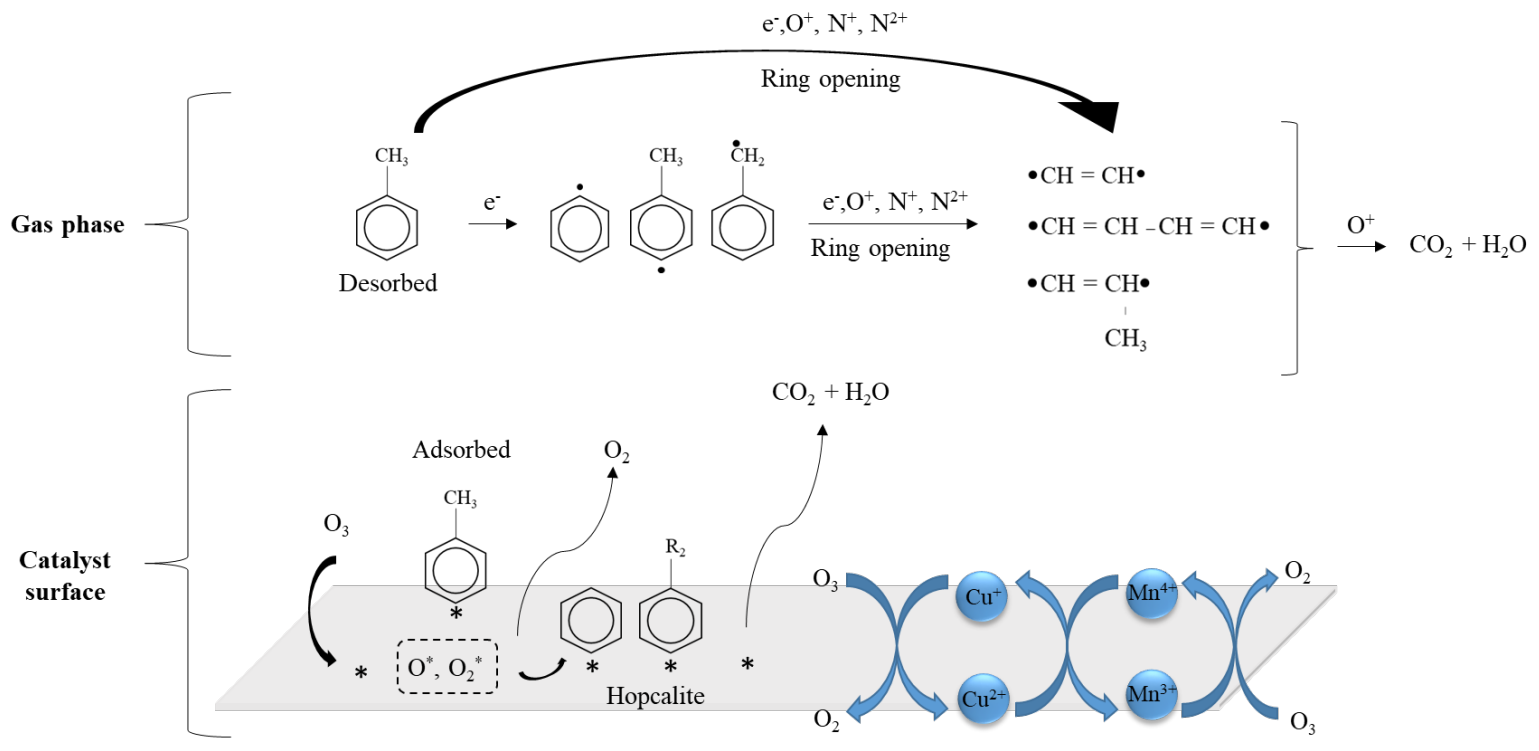

Fig. 14 Plausible degradation route for desorbed toluene and adsorbed toluene in gas phase and on the catalyst surface, respectively.

For the degradation of gas phase toluene which is desorbed from Hopcalite, the following energetic electron impact dissociations and radical impact dissociations form the reaction scheme [47-49]:

$$
\begin{aligned}
& \mathrm{C}_{6} \mathrm{H}_{5} \cdot \mathrm{CH}_{3}+e^{-} \rightarrow \mathrm{C}_{6} \mathrm{H}_{5}+\mathrm{CH}_{3}+e^{-} \\
& \mathrm{C}_{6} \mathrm{H}_{5} \cdot \mathrm{CH}_{3}+e^{-} \rightarrow \mathrm{C}_{6} \mathrm{H}_{4} \cdot \mathrm{CH}_{3}+\mathrm{H}+e^{-} \\
& \mathrm{C}_{6} \mathrm{H}_{5} \cdot \mathrm{CH}_{3}+e^{-} \rightarrow \mathrm{C}_{5} \mathrm{H}_{6}+\mathrm{C}_{2} \mathrm{H}_{2}+e^{-} \\
& \mathrm{C}_{6} \mathrm{H}_{5} \cdot \mathrm{CH}_{3}+e^{-} \rightarrow \mathrm{C}_{3} \mathrm{H}_{4}+\mathrm{C}_{4} \mathrm{H}_{4}+e^{-} \\
& \mathrm{C}_{6} \mathrm{H}_{5} \cdot \mathrm{CH}_{3}+\mathrm{O}^{+}, \mathrm{O}_{2}^{+}, \mathrm{N}, \mathrm{N}_{2}^{+} \rightarrow \mathrm{C}_{6} \mathrm{H}_{5} \cdot \mathrm{CH}_{3}+\mathrm{O}_{2} \mathrm{O}_{3}, \mathrm{~N}, \mathrm{~N}_{2}
\end{aligned}
$$

The reaction of the above formed intermediates and toluene with radicals such as $\mathrm{O}^{+}, \mathrm{N}^{+}$ and $\mathrm{N}_{2}{ }^{+}$leads to the formation of $\mathrm{CO}_{2}$ and $\mathrm{H}_{2} \mathrm{O}$. The formation of $\mathrm{N}_{2} \mathrm{O}$ involves the species produced by electron collisions on $\mathrm{N}_{2}$ and $\mathrm{O}_{2}$ following the reactions [50]: 


$$
\begin{aligned}
& \mathrm{N}_{2}^{*}+\mathrm{O}_{2} \rightarrow \mathrm{N}_{2} \mathrm{O}+\mathrm{O}^{*} \\
& \mathrm{~N}+\mathrm{NO}_{2} \rightarrow \mathrm{N}_{2} \mathrm{O}+\mathrm{O}^{*}
\end{aligned}
$$

According to MVK mechanism, the adsorbed organic species are oxidized by the lattice oxygen and the gas phase oxygen re-oxidizes the oxygen vacancy $[51,52]$. Thus, the presence of metal couples with different oxidation state which can be easily oxidized and reduced in the reaction cycle is crucial [53]. Based on the XPS results, the presence of $\mathrm{Mn}^{3+}$ and $\mathrm{Cu}^{2+}$ in Hopcalite can result in solid state charge transfer redox system.

$$
\mathrm{Cu}^{2+}+\mathrm{Mn}^{3+} \rightarrow \mathrm{Cu}^{+}+\mathrm{Mn}^{4+}
$$

Oyama et al [54] reported that the ozone decomposition ability of the p-type oxide catalysts such as $\mathrm{MnO}_{\mathrm{x}}$ is higher than the n-type oxide catalysts. Thus, according to the equations (16)(18), ozone can be efficiently adsorbed decomposed by Lewis acid sites of manganese oxide in Hopcalite to form oxygen species. Liang et al [55] proposed that the oxidation of $\mathrm{CO}$ on $\mathrm{MnO}_{2}$ nanorods could occur by the adsorption of gas phase $\mathrm{CO}$ on the active oxygen species of the catalyst. It has been reported that the CO yield of reactor used $(<1 \%)$ in dry air NTP discharge and this is a reasonable explanation for the oxidation of $\mathrm{CO}$ to $\mathrm{CO}_{2}$. According to $\mathrm{MVK}$ mechanism, it is reasonable to propose that the adsorbed toluene which are converted by NTP discharge and the intermediate products of toluene oxidation reacts with the lattice oxygen to form $\mathrm{CO}_{2}$ and $\mathrm{H}_{2} \mathrm{O}$ and creates oxygen vacancies. The presence of the redox couple in Hopcalite results in the continuous charge transfer and the reduced metal oxide is replenished by the active 
oxygen formed by the decomposition of ozone [56-58]. Thus, the reducibility of the metal oxide and replenishing of the oxygen vacancies are the rate determining step in the oxidation of toluene in Hopcalite packed bed DBD reactor.

$$
\begin{aligned}
& \mathrm{O}_{3}+* \rightarrow \mathrm{O}_{2}+\mathrm{O}^{*} \\
& \mathrm{O}_{3}+\mathrm{O}^{*} \rightarrow \mathrm{O}_{2}^{*}+\mathrm{O}_{2} \\
& \mathrm{O}_{2}^{*} \rightarrow \mathrm{O}_{2}+* \\
& \mathrm{O}^{*}+\mathrm{CO} \rightarrow \mathrm{CO}_{2}+* \\
& 18 \mathrm{O}^{*}+\mathrm{C}_{7} \mathrm{H}_{8}^{*} \rightarrow 7 \mathrm{CO}_{2}+4 \mathrm{H}_{2} \mathrm{O}
\end{aligned}
$$

where * denotes the active sites on the surface of the catalyst.

\section{Conclusion}

A DBD reactor packed with Hopcalite and glass beads was investigated for the adsorption plasma catalysis for the oxidation of adsorbed toluene on Hopcalite and the regeneration of the used Hopcalite by NTP discharge. The main carbon containing gaseous product formed during the NTP discharge is $\mathrm{CO}_{2}$ where $\sim 86 \%$ of the abated toluene has been converted to this $\mathrm{CO}_{2}$ using fresh calcined Hopcalite. The similar amount of irreversibly adsorbed toluene with respect to the total amount of adsorbed toluene on fresh calcined and NTP (I) regenerated Hopcalite suggests a good regeneration of Hopcalite by a NTP discharge. The carbon balance and $\mathrm{CO}_{2}$ selectivity during the NTP oxidation of irreversibly adsorbed toluene on NTP (I) regenerated Hopcalite proves that the catalytic activity of NTP regenerated Hopcalite is slightly 
better than that of the fresh calcined Hopcalite. This is mainly explained by the higher ratio of $\mathrm{O}_{a} / \mathrm{O}_{1}$ for NTP regenerated Hopcalite when compared to the fresh calcined Hopcalite. The XRD spectra, elemental composition and oxidation state of metals demonstrate the regeneration of the used Hopcalite. The first NTP regeneration induces partial transformation of amorphous Hopcalite into $\mathrm{Mn}_{3} \mathrm{O}_{4}$ with no detected crystallized $\mathrm{CuO}_{\mathrm{x}}$ oxides and decreases $\mathrm{S}_{\mathrm{BET}}$ by a factor 2 ; however, without significantly modifying the toluene adsorption capacity. Thus the structure of the Hopcalite is stabilized after the NTP (I) regeneration which is evident from the XRD patterns and $\mathrm{S}_{\mathrm{BET}}$ of NTP (I) and NTP (II) regenerated Hopcalite.

Thus, three of the four main criteria for the selection of catalysts for adsorption plasma catalysis of VOCs such as good oxidation ability for the total oxidation of VOCs, stability of catalyst in NTP discharge and ability to be regenerated by NTP discharge are fulfilled by Hopcalite. However, further work has to be done to increase the proportion of converted toluene with respect to total adsorption capacity and thus to improve the overall efficiency of the process.

\section{Acknowledgments}

The "DepollutAir" project of the European Program INTERREG V France-Wallonie-Flanders FEDER is acknowledged for supporting and funding this research work (grant number 1.1.18). This research was carried out in the French-Belgium Associated International Laboratory "Plasma \& Catalysis" supported by the University of Lille and Ghent University.

\section{References}


[1] M. Hodgson, H. Levin, P. Wolkoff, S. Cruz, Volatile organic compounds and indoor air, J. Allergy Clin. Immunol. 94 (1994) 296-303. doi:10.1053/ai.1994.v94.a56008.

[2] H. Nakaoka, E. Todaka, H. Seto, I. Saito, M. Hanazato, M. Watanabe, C. Mori, Correlating the symptoms of sick-building syndrome to indoor VOCs concentration levels and odour, Indoor Built Environ. $23 \quad$ (2014) 804-813. doi:10.1177/1420326X13500975.

[3] L. Massolo, M. Rehwagen, A. Porta, A. Ronco, O. Herbarth, A. Mueller, Indoor-outdoor distribution and risk assessment of volatile organic compounds in the atmosphere of industrial and urban areas, Environ. Toxicol. 25 (2009) 339-349. doi:10.1002/tox.20504.

[4] C.O. Baltaretu, E.I. Lichtman, A.B. Hadler, M.J. Elrod, Primary atmospheric oxidation mechanism for toluene, J. Phys. Chem. A. 113 (2009) 221-230. doi:10.1021/jp806841t.

[5] M.-W. Cho, J. Kim, J.M. Jeong, B. Yim, H.-J. Lee, Y. Yoo, Excellent toluene removal via adsorption by honeycomb adsorbents under high temperature and humidity conditions, Environ. Eng. Res. 25 (2020) 171-177. doi:10.4491/eer.2018.444.

[6] C. Lorimier, A. Subrenat, L. Le Coq, P. Le Cloirec, Adsorption of Toluene onto Activated Carbon Fibre Cloths and Felts: Application to Indoor Air Treatment, Environ. Technol. 26 (2005) 1217-1230. doi:10.1080/09593332608618600.

[7] L. Karimnezhad, M. Haghighi, E. Fatehifar, Adsorption of benzene and toluene from waste gas using activated carbon activated by ZnCl2, Front. Environ. Sci. Eng. 8 (2014) 
835-844. doi:10.1007/s11783-014-0695-4.

[8] L. Li, F. Jing, J. Yan, J. Jing, W. Chu, Highly effective self-propagating synthesis of CeO2-doped $\mathrm{MnO} 2$ catalysts for toluene catalytic combustion, Catal. Today. 297 (2017) 167-172. doi:10.1016/J.CATTOD.2017.04.053.

[9] Y. Peng, L. Zhang, L. Chen, D. Yuan, G. Wang, X. Meng, F.-S. Xiao, Catalytic performance for toluene abatement over Al-rich Beta zeolite supported manganese oxides, Catal. Today. 297 (2017) 182-187. doi:10.1016/J.CATTOD.2017.04.058.

[10] C. Belver, M.J. López-Muñoz, J.M. Coronado, J. Soria, Palladium enhanced resistance to deactivation of titanium dioxide during the photocatalytic oxidation of toluene vapors, Appl. Catal. B Environ. 46 (2003) 497-509. doi:10.1016/S0926-3373(03)00291-1.

[11] G. Xiao, W. Xu, R. Wu, M. Ni, C. Du, X. Gao, Z. Luo, K. Cen, Non-Thermal Plasmas for VOCs Abatement, Plasma Chem. Plasma Process. 34 (2014) 1033-1065. doi:10.1007/s11090-014-9562-0.

[12] A. Berenjian, N. Chan, H.J. Malmiri, Volatile Organic Compounds Removal Methods: A Review, Am. J. Biochem. Biotechnol. $8 \quad$ (2012) 220-229. doi:10.3844/ajbbsp.2012.220.229.

[13] S. Mudliar, B. Giri, K. Padoley, D. Satpute, R. Dixit, P. Bhatt, R. Pandey, A. Juwarkar, A. Vaidya, Bioreactors for treatment of VOCs and odours - A review, J. Environ. Manage. 91 (2010) 1039-1054. doi:10.1016/j.jenvman.2010.01.006. 
[14] K. Urashima, J.S. Chang, Removal of volatile organic compounds from air streams and industrial flue gases by non-thermal plasma technology, IEEE Trans. Dielectr. Electr. Insul. 7 (2000) 602-614. doi:10.1109/94.879356.

[15] M.B. Chang, C.-C. Chang, Destruction and removal of toluene and MEK from gas streams with silent discharge plasmas, AIChE J. 43 (1997) 1325-1330. doi:10.1002/aic.690430521.

[16] Y. Wan, X. Fan, T. Zhu, Removal of low-concentration formaldehyde in air by DC corona discharge plasma, Chem. Eng. J. 171 (2011) 314-319. doi:10.1016/J.CEJ.2011.04.011.

[17] C.L. Chang, H. Bai, S.J. Lu, Destruction of styrene in an air stream by packed dielectric barrier discharge reactors, Plasma Chem. Plasma Process. 25 (2005) 641-657. doi:10.1007/s11090-005-6818-8.

[18] A.M. Vandenbroucke, R. Morent, N. De Geyter, C. Leys, Decomposition of toluene with plasma-catalysis: A review, J. Adv. Oxid. Technol. 15 (2012) 232-241.

[19] B. Wang, C. Chi, M. Xu, C. Wang, D. Meng, Plasma-catalytic removal of toluene over $\mathrm{CeO} 2-\mathrm{MnOx}$ catalysts in an atmosphere dielectric barrier discharge, Chem. Eng. J. 322 (2017) 679-692. doi:10.1016/J.CEJ.2017.03.153.

[20] T. Wang, S. Chen, H. Wang, Z. Liu, Z. Wu, In-plasma catalytic degradation of toluene over different $\mathrm{MnO} 2$ polymorphs and study of reaction mechanism, Chinese J. Catal. 38 (2017) 793-803. doi:10.1016/S1872-2067(17)62808-0. 
[21] X. Xu, P. Wang, W. Xu, J. Wu, L. Chen, M. Fu, D. Ye, Plasma-catalysis of metal loaded SBA-15 for toluene removal: Comparison of continuously introduced and adsorptiondischarge plasma system, Chem. Eng. J. 283 (2016) 276-284. doi:10.1016/j.cej.2015.07.050.

[22] X. Xu, J. Wu, W. Xu, M. He, M. Fu, L. Chen, A. Zhu, D. Ye, High-efficiency non-thermal plasma-catalysis of cobalt incorporated mesoporous MCM-41 for toluene removal, Catal. Today. 281 (2017) 527-533. doi:10.1016/j.cattod.2016.03.036.

[23] X. Yao, J. Zhang, X. Liang, C. Long, Plasma-catalytic removal of toluene over the supported manganese oxides in DBD reactor: Effect of the structure of zeolites support, Chemosphere. 208 (2018) 922-930. doi:10.1016/J.CHEMOSPHERE.2018.06.064.

[24] W. Xu, N. Wang, Y. Chen, J. Chen, X. Xu, L. Yu, L. Chen, J. Wu, M. Fu, A. Zhu, D. Ye, In situ FT-IR study and evaluation of toluene abatement in different plasma catalytic systems over metal oxides loaded $\gamma$-A12O3, Catal. Commun. 84 (2016) 61-66. doi:10.1016/J.CATCOM.2016.06.004.

[25] J.C. Whitehead, Plasma-catalysis: the known knowns, the known unknowns and the unknown unknowns, J. Phys. D. Appl. Phys. 49 (2016) 243001.

[26] L. Sivachandiran, F. Thevenet, P. Gravejat, A. Rousseau, Isopropanol saturated TiO 2 surface regeneration by non-thermal plasma: influence of air relative humidity, Chem. Eng. J. 214 (2013) 17-26. 
[27] S. Sultana, A.M. Vandenbroucke, C. Leys, N. De Geyter, R. Morent, Abatement of VOCs with alternate adsorption and plasma-assisted regeneration: A review, Catalysts. 5 (2015) 718-746. http://www.mdpi.com/2073-4344/5/2/718/.

[28] D. Zhao, X. Li, C. Shi, H. Fan, A. Zhu, Low-concentration formaldehyde removal from air using a cycled storage-discharge (CSD) plasma catalytic process, Chem. Eng. Sci. 66 (2011) 3922-3929. http://dx.doi.org/10.1016/j.ces.2011.05.019.

[29] W. Wang, H. Wang, T. Zhu, X. Fan, Removal of gas phase low-concentration toluene over Mn, Ag and Ce modified HZSM-5 catalysts by periodical operation of adsorption and non-thermal plasma regeneration, J. Hazard. Mater. 292 (2015) 70-78. http://dx.doi.org/10.1016/j.jhazmat.2015.03.013.

[30] S. Dey, G.C. Dhal, Deactivation and regeneration of hopcalite catalyst for carbon monoxide oxidation: a review, Mater. Today Chem. 14 (2019) 100180. doi:10.1016/j.mtchem.2019.07.002.

[31] H.-Y. Fan, C. Shi, X.-S. Li, D.-Z. Zhao, Y. Xu, A.-M. Zhu, High-efficiency plasma catalytic removal of dilute benzene from air, J. Phys. D. Appl. Phys. 42 (2009) 225105.

[32] L. Sivachandiran, F. Thevenet, A. Rousseau, Isopropanol removal using MnXOY packed bed non-thermal plasma reactor: Comparison between continuous treatment and sequential sorption/regeneration, Chem. Eng. J. $270 \quad$ (2015) 327-335. doi:10.1016/J.CEJ.2015.01.055. 
[33] M. Ansari, A. Hossein Mahvi, M. Hossein Salmani, M. Sharifian, H. Fallahzadeh, M. Hassan Ehrampoush, Dielectric barrier discharge plasma combined with nano catalyst for aqueous amoxicillin removal: Performance modeling, kinetics and optimization study, energy yield, degradation pathway, and toxicity, Sep. Purif. Technol. 251 (2020) 117270. doi:10.1016/j.seppur.2020.117270.

[34] D.R. Merrill, C.C. Scalione, The catalytic oxidation of carbon monoxide at ordinary temperatures, J. Am. Chem. Soc. 43 (1921) 1982-2002. doi:10.1021/ja01442a002.

[35] Z. Ye, J.-M. Giraudon, N. Nuns, P. Simon, N. De Geyter, R. Morent, J.-F. Lamonier, Influence of the preparation method on the activity of copper-manganese oxides for toluene total oxidation, Appl. Catal. B Environ. 223 (2018) 154-166. doi:10.1016/j.apcatb.2017.06.072.

[36] X. Li, L. Wang, Q. Xia, Z. Liu, Z. Li, Catalytic oxidation of toluene over copper and manganese based catalysts: Effect of water vapor, Catal. Commun. 14 (2011) 15-19. doi:10.1016/j.catcom.2011.07.003.

[37] M. Zimowska, A. Michalik-Zym, R. Janik, T. Machej, J. Gurgul, R.P. Socha, J. Podobiński, E.M. Serwicka, Catalytic combustion of toluene over mixed Cu-Mn oxides, Catal. Today. 119 (2007) 321-326. doi:10.1016/j.cattod.2006.08.022.

[38] M.I. Brittan, H. Bliss, C.A. Walker, Kinetics of the Hopcalite-catalyzed oxidation of carbon monoxide, AIChE J. 16 (1970) 305-314. doi:10.1002/aic.690160226. 
[39] S. Sultana, A.M. Vandenbroucke, M. Mora, C. Jiménez-Sanchidrián, F.J. RomeroSalguero, C. Leys, N. De Geyter, R. Morent, Post plasma-catalysis for trichloroethylene decomposition over $\mathrm{CeO} 2$ catalyst: Synergistic effect and stability test, Appl. Catal. B Environ. 253 (2019) 49-59. doi:10.1016/J.APCATB.2019.03.077.

[40] S. Vepřek, D.L. Cocke, S. Kehl, H.R. Oswald, Mechanism of the deactivation of Hopcalite catalysts studied by XPS, ISS, and other techniques, J. Catal. (1986). doi:10.1016/0021-9517(86)90090-4.

[41] Z. Ye, S. Kaliya Perumal Veerapandian, I. Onyshchenko, A. Nikiforov, N. De Geyter, J.M. Giraudon, J.-F. Lamonier, R. Morent, An in-depth investigation of toluene decomposition with a glass beads packed bed DBD reactor, Ind. Eng. Chem. Res. (2017) acs.iecr.7b00963. doi:10.1021/acs.iecr.7b00963.

[42] S.S. Kireev, V.M. Mukhin, S.G. Kireev, V.N. Klushin, S.N. Tkachenko, Preparation and properties of modified Hopcalite, Russ. J. Appl. Chem. 82 (2009) 169-171. doi:10.1134/S1070427209010339.

[43] A. Davó-Quiñonero, M. Navlani-García, D. Lozano-Castelló, A. Bueno-López, $\mathrm{CuO} /$ crytomelane catalyst for preferential oxidation of $\mathrm{CO}$ in the presence of $\mathrm{H} 2$ : deactivation and regeneration, Cite This Catal. Sci. Technol. 6 (2014) 5684. doi:10.1039/c6cy00329j.

[44] V.P. Santos, M.F.R. Pereira, J.J.M. Órfão, J.L. Figueiredo, The role of lattice oxygen on 
the activity of manganese oxides towards the oxidation of volatile organic compounds, Appl. Catal. B Environ. 99 (2010) 353-363. doi:10.1016/J.APCATB.2010.07.007.

[45] A. Worayingyong, P. Kangvansura, S. Ausadasuk, P. Praserthdam, The effect of preparation: Pechini and Schiff base methods, on adsorbed oxygen of LaCoO3 perovskite oxidation catalysts, Colloids Surfaces A Physicochem. Eng. Asp. 315 (2008) 217-225. doi:10.1016/J.COLSURFA.2007.08.002.

[46] S.-M. Bak, K.-W. Nam, C.-W. Lee, K.-H. Kim, H.-C. Jung, X.-Q. Yang, K.-B. Kim, Spinel LiMn 2 O 4 /reduced graphene oxide hybrid for high rate lithium ion batteries $\dagger$, (n.d.). doi:10.1039/c1jm13741g.

[47] W. Liang, J. Li, J. Li, Y. Jin, Abatement of toluene from gas streams via ferro-electric packed bed dielectric barrier discharge plasma, J. Hazard. Mater. 170 (2009) 633-638. doi:10.1016/j.jhazmat.2009.05.019.

[48] W.J. Liang, L. Ma, H. Liu, J. Li, Toluene degradation by non-thermal plasma combined with a ferroelectric catalyst, Chemosphere. $92 \quad$ (2013) 1390-1395. doi:10.1016/j.chemosphere.2013.05.042.

[49] Y. fang Guo, D. qi Ye, K. fu Chen, J. cong He, Toluene removal by a DBD-type plasma combined with metal oxides catalysts supported by nickel foam, Catal. Today. 126 (2007) 328-337. doi:10.1016/j.cattod.2007.06.025.

[50] N. Blin-Simiand, F. Jorand, L. Magne, S. Pasquiers, C. Postel, J.-R. Vacher, Plasma 
reactivity and plasma-surface interactions during treatment of toluene by a dielectric barrier discharge, Plasma Chem. Plasma Process. 28 (2008) 429-466.

[51] S. Behar, N.A. Gómez-Mendoza, M.Á. Gómez-García, D. Wwierczyński, F. Quignard, N. Tanchoux, Study and modelling of kinetics of the oxidation of VOC catalyzed by nanosized Cu-Mn spinels prepared via an alginate route, Appl. Catal. A Gen. 504 (2015) 203-210. doi:10.1016/j.apcata.2014.12.021.

[52] C. Doornkamp, V. Ponec, The universal character of the Mars and Van Krevelen mechanism, J. Mol. Catal. A Chem. 162 (2000) 19-32. doi:10.1016/S13811169(00)00319-8.

[53] S. Behar, P. Gonzalez, P. Agulhon, F. Quignard, D. Świerczyński, New synthesis of nanosized $\mathrm{Cu}-\mathrm{Mn}$ spinels as efficient oxidation catalysts, in: Catal. Today, Elsevier, 2012: pp. 35-41. doi:10.1016/j.cattod.2012.04.004.

[54] S.T. Oyama, Chemical and Catalytic Properties of Ozone, Catal. Rev. - Sci. Eng. 42 (2000) 279-322. doi:10.1081/CR-100100263.

[55] S. Liang, F. Teng, G. Bulgan, R. Zong, Y. Zhu, Effect of phase structure of MnO2 nanorod catalyst on the activity for CO oxidation, J. Phys. Chem. C. 112 (2008) 53075315. doi:10.1021/jp0774995.

[56] C.W. Kwong, C.Y.H. Chao, K.S. Hui, M.P. Wan, Removal of VOCs from indoor environment by ozonation over different porous materials, Atmos. Environ. 42 (2008) 
2300-2311. doi:10.1016/j.atmosenv.2007.12.030.

[57] Y. Xi, C. Reed, Y.-K. Lee, S.T. Oyama, Acetone Oxidation Using Ozone on Manganese Oxide Catalysts, (2005). doi:10.1021/jp052930g.

[58] E. Rezaei, J. Soltan, Low temperature oxidation of toluene by ozone over $\mathrm{MnOx} / \gamma$ alumina and MnOx/MCM-41 catalysts, Chem. Eng. J. 198-199 (2012) 482-490. doi:10.1016/j.cej.2012.06.016. 